\title{
The intonation of the Q-marking construction: a comparison of Hungarian and Slovenian ${ }^{1}$
}

\author{
LOUISE MYCOCK \\ Somerville College, University of Oxford \\ ORCiD ID: 0000-0003-3473-0979
}

This paper examines the Q-marking construction: an interrogative construction in which a question phrase takes scope over a higher clause even though it appears in a lower clause. In this construction, the scope of a question phrase is extended by the presence of another word, the Q-marker, in a higher clause. While the syntax of this construction has been described and analysed in a number of works, its intonation is yet to receive commensurate attention. This paper presents data from two unrelated languages in which the Q-marking construction can be used to form questions: Hungarian and Slovenian. Data show that while the Q-marker shares properties with question phrases in Hungarian (they bear the same pitch accent), in Slovenian the Q-marker bears a distinct pitch accent. Furthermore, in Hungarian a direct intonational link exists between the Q-marker and a question phrase whose scope is extended, rather than an indirect one between the Q-marker and the entire lower clause in which the question phrase appears. The Slovenian data are compatible with the existence of either an indirect or a direct intonational link. These findings reveal hitherto unidentified dimensions of crosslinguistic variation, for which any analysis of the Q-marking construction must account.

wh-scope marking, intonation, long-distance dependency, Hungarian, Slovenian 


\section{INTRODUCTION}

The analysis of question-word ('wh') questions has played a central role in the development of modern linguistic theory. In particular, describing and accounting for cross-linguistic variation represents a challenge that any theory must demonstrate that it is able to meet. Much work has concentrated on variation in terms of the syntax of question-word questions (for instance, Chomsky 1977, Rudin 1988, Cheng 1997, Mycock 2006), but increasingly prosody is being considered as well, giving a more complete picture not only of the possible variation with respect to question formation, but also of how prosody, syntax, and semantics can and do interact at the interface.

This paper investigates for the first time the intonation of one particular question formation strategy from a comparative perspective: the Q-marking construction. ${ }^{2}$ This is a construction in which the interrogativity associated with a question phrase appears to extend over a clause higher than the one in which it appears: a question phrase appears to TAKE SCOPE OVER a higher clause. To illustrate, let us first consider one way in which question-word questions can be formed in German. The questions in (1) exemplify simple fronting: a question phrase (in bold) occupies initial position in the interrogative clause (that is, in the clause over which it takes scope). The interrogative clause may be the matrix clause (matrix interrogative scope, a matrix question), as in (1a), or a subordinate clause (embedded interrogative scope, an embedded question), as in (1b). The extent of interrogative scope is indicated by underlining.

(1) German

(a) simple fronting; matrix question (matrix interrogative scope)

Wann glaubst du, [dass sie gekommen ist]?

when think.2SG you that she come.PTCP is

'When do you think she came?' 
(Staudacher 2000: 195)

(b) simple fronting; embedded question (embedded interrogative scope)

Ich fragte, [wann sie gekommen ist].

I ask.PST.1SG when she come.PTCP is

'I asked when she came.'

The Q-marking construction is also used to form questions in German. It is fundamentally different to simple fronting because the question phrase (again in bold) occupies initial position in a clause lower than the one over which interrogativity extends. Notice that (2) is a matrix question - it receives the same translation as (1a) despite the question word wann 'when' appearing at the start of the subordinate clause, making the subordinate clause in (2) identical to the embedded question in (1b). The extent of interrogativity in (2), indicated once again by underlining, is consistent not with this question word's position, as was the case in (1), but with the presence of a Qmarker (glossed throughout as QM and given here in capitals) in the higher clause; notice that the Q-marker was appears in sentence-initial position in the matrix clause in (2).

(2) Q-marking construction; matrix question

WAS glaubst du, [wann sie gekommen ist]?

QM think.2SG you when she come.PTCP is

'When do you think she came?'

(Staudacher 2000: 195)

While the syntax of scope-marking constructions and its analysis has been a topic of interest in the literature for some time, their intonation has to date received little attention. If intonation is mentioned, it is usually based on impressionistic observation and invoked in support of the claim that rather than two separate questions (What do 
you think? When did she come?), a scope-marking construction is in fact a single sentence (e.g. McDaniel 1989, Felser 2001).

My focus in this paper is on documenting and analysing the intonation of the Qmarking construction in two unrelated case-study languages in order to identify any common features and how they may differ. This provides the basis for evaluating those analyses of Q-marking, formulated on the basis of the construction's syntax and semantics, that exist in the literature. It is to be hoped that this work represents a first step towards further investigation of the intonation of Q-marking constructions crosslinguistically, which will ultimately afford us a better understanding of question formation strategies more broadly; that is, encompassing the syntactic and semantic as well as the prosodic aspects of their form. This foundational work is essential if we are to evaluate fully approaches to the analysis of question formation and the theories within which these are formulated.

I begin by providing a description of the Q-marking construction's key characteristics (Section 2) and information about the speech data collected and analysed for this study (Section 3), before moving on to the two case-study languages: Hungarian (Section 4) and Slovenian (Section 5). These languages were selected because they both employ the same question-word question formation strategy in addition to Q-marking; they are unrelated (Hungarian is a Finno-Ugric language, while Slovenian belongs to the Slavic family); and their respective syntactic and phonological structures have already been described in the literature, albeit to varying extents. For each case-study language, relevant background information on its syntax and intonation are provided with respect to declaratives, and single and multiple question-word questions, before the syntax and intonation of the Q-marking construction are described and analysed. In 
Section 6, I compare the intonation of the Q-marking construction in the case-study languages and consider the implications of my findings for two previously proposed analyses of the Q-marking construction: the direct dependency analysis (Riemsdijk 1983, McDaniel 1989) and the indirect dependency analysis (Dayal 1994, 2000). The conclusion is presented in Section 7.

This paper seeks to engage with and stimulate debate in relation to syntax, prosody, and the interaction between the two by making its findings accessible to both those who may be familiar (or more familiar) with analysis and issues relating to one of these aspects of linguistic structure, as well as those already well-versed in matters of the syntax-prosody interface. For this reason, data are analysed in terms that are as theory-neutral as possible.

\section{THE Q-MARKING CONSTRUCTION: AN OVERVIEW}

Constructions in which interrogative scope extends over a clause higher than the one in which a question phrase appears are found in all three types of language identified in the traditional typology of question-word questions. That is, such scopemarking constructions have been identified in languages in which the question formation strategy employed is simple fronting (e.g. German; see Staudacher 2000 and example 1); multiple fronting (e.g. Hungarian; see Horvath 1997 and Section 4.1); and in situ, meaning that there is no apparent displacement of question phrases to a position of prominence (e.g. Malay; Cole \& Hermon 2000). My two case-study languages are Hungarian and Slovenian, which are both multiple-fronting languages: all question words in a question appear to have been displaced (rather than one, as is the case in German or English). 
In this paper, I focus on one particular type of scope-marking construction: the Qmarking construction. ${ }^{3}$ For the purposes of this paper, the defining properties of the Qmarking construction are: (i) extension of scope, plus (ii) the presence of the Q-marker. ${ }^{4}$ Below, each of these properties is illustrated with examples from the languages taken as case studies in this paper, viz. Hungarian [Hgn] and Slovenian [S1].

(i) Extension of scope: The scope of any number of question phrases in a lower clause extends over a higher clause than the one in which they appear.

In (3) and (4), the Q-marker (in capitals) extends the scope of the question phrases (in bold) so that they take matrix scope despite appearing in a lower clause.

(3) (a) István MI-T gondol, [hogy János ki-t István.NOM QM-ACC think.3SG that János.NOM who-ACC hívott fel]? called.3SG VM 'Who does István think that János called?' [Hgn]

(b) István MI-T gondol, [hogy ki ki-t István.NOM QM-ACC think.3SG that who.NOM who-ACC hívott fel]? called.3SGVM 'Who does István think called who?' [Hgn]

(4) (a) KAJ je Miha mislil, [koga da je QM.ACC AUX.3SG Miha.NOM think.PTCP.SG who.ACC that AUX.3SG Roman hvalil Heleni]?

Roman.NOM praise.PTCP.SG Helena.DAT 'Who did Miha think Roman praised to Helena?' [Sl]

(b) KAJ je Miha mislil, [kdo da je

QM.ACC AUX.3SG Miha.NOM think.PTCP.SG who.NOM that AUX.3SG

koga Heleni hvalil]?

who.ACC Helena.DAT praise.PTCP.SG

'Who did Miha think praised who to Helena?' [Sl] 
(ii) Presence of the Q-marker: Extended interrogative scope is marked by the presence of a Q-marker in a higher clause in this construction. The Q-marker occupies the same syntactic position as a question word would.

Observe the immediately preverbal position of both Q-markers and question phrases in the Hungarian examples in (3), and their clause-initial position in the Slovenian examples in (4). When scope extension involves more than one subordinate and one matrix clause, any Q-marker (in capitals) occupies that same position in clauses that intervene between the question phrase and the highest occurrence of the Q-marker:

(5) István MI-T gondol, [hogy Ilona MI-T akar, István.NOM QM-ACC think.3SG that Ilona.NOM QM-ACC want.3SG [hogy János ki-t hív-j-on fel]]? that János.NOM who-ACC call-SBJV-3SG VM 'Who does István think that Ilona wants János to call?' [Hgn]

(6) KAJ nam je Vid ukazal, [KAJ moremo QM.ACC 1PL.DAT AUX.3SG Vid.NOM order.PTCP.SG QM.ACC must reči [koga je Marija poljubila]]? say.INF who.ACC AUX.3SG Marija.NOM kiss.PTCP.SG 'Who did Vid order us that we must say that Marija kissed?' [S1]

(Marušič 2008: 415)

The question phrase whose scope is extended may appear in an intermediate clause, i.e. in a clause higher than the one in which it bears a grammatical function but lower than the one over which it takes scope. For example in (7), despite kit 'who' being the object of the verb felhivta 'called' in the most deeply embedded clause, this question phrase appears in a higher clause but not in the matrix clause over which interrogative scope 
extends (i.e over the entire sentence, making it a matrix question). The same applies in the case of the Slovenian example in (8).

(7) István MI-T gondol, [hogy Mari ki-t mondott, [hogy

István.NOM QM-ACC think.3SG that Mari.NOM who-ACC said.3SG that János fel-hívta]]?

János.NOM VM-called.3SG

'Who does István think that Mari said that János called?' [Hgn]

(8) KAJ je Miha mislil, [koga da je

QM.ACC AUX.3SG Miha.NOM think.PTCP.SG who.ACC that AUX.3SG

Manuela rekla [da je Roman hvalil

Manuela.NOM say.PTCP.SG that AUX.3SG Roman.NOM praise.PTCP.SG

Heleni]]?

Helena.DAT

'Who did Miha think that Manuela said that Roman praised to Helena?' [Sl]

Whether a Q-marker is obligatory in every clause between the question phrase and the highest occurrence of the Q-marker varies cross-linguistically. In Hungarian, the Qmarker's presence is obligatory; this is not the case in Slovenian, where an intervening clause need not include a Q-marker:

(9) KAJ je Miha mislil, [da je Manuela

QM.ACC AUX.3SG Miha.NOM think.PTCP.SG that AUX.3SG Manuela.NOM rekla, [koga da je Roman hvalil Heleni]]? say.PTCP.SG who.ACC that AUX.3SG Roman.NOM praise.PTCP.SG Helena.DAT 'Who did Miha think that Manuela said that Roman praised to Helena?' [S1]

These properties distinguish the Q-marking construction from other types of question formation strategies.

Previous analyses such as Riemsdijk (1983), McDaniel (1989), and Dayal (1994, 2000) have sought to address two key related issues. Firstly, what is the status of the Q- 
marker? (Is it a question word itself, or an expletive element?) Secondly, is the relationship between the Q-marker and the question word(s) in a lower clause direct or indirect?

Discussion in the literature has centred on whether the Q-marker is an expletive element inserted only in order to extend the scope of question phrases (e.g. Riemsdijk 1983, McDaniel 1989) or is itself a question word, viz. one used to enquire about propositions (Dayal 1994, 2000). The former is known as the direct dependency analysis. According to this analysis, the Q-marking construction and an equivalent question-word question are analysed as being identical in their interpretation; there is a DIRECT link between the expletive element that stands in for the question phrase (i.e. the Q-marker) and the question phrase itself. (Compare with other expletive constructions and their equivalents; for example It is difficult to wait patiently for the results and To wait patiently for the results is difficult.) Under the second type of analysis, by contrast, the Q-marker is a question word itself. This question word is related to the entire lower clause containing the relevant question phrase(s), so the relationship between the Qmarker and question phrase is INDIRECT. Under an indirect dependency approach, the German Q-marking construction in (2) would be paraphrased more accurately as: 'For which proposition $q$, where $q$ is the answer to the question When did she come?, you think $q$ ?' According to the indirect dependency analysis then, the lower clause is a question-word question (When did she come?) and the Q-marker is a question word that relies on the meaning of the lower clause for its interpretation, as indicated by the paraphrase provided for (2). The key differences between these two approaches to the analysis of the Q-marking construction are therefore whether or not the Q-marker is a 
question word itself, and whether the relationship between the Q-marker and the question phrase(s) in a lower clause is direct or indirect.

This paper considers whether the Q-marking construction displays the same properties as a question-word question with respect to the sentence's intonational structure, a dimension of this construction that has not yet received the attention that it surely warrants and which will contribute to a fuller evaluation of which analysis - the direct or indirect analysis - is the most appropriate for the Q-marking construction.

The hypotheses (Hs) to be tested are:

H1: Q-markers display the same intonational characteristics (i.e. bear the same pitch accent) as question words (in line with the indirect dependency analysis).

$\mathrm{H} 2$ : The intonational characteristics of the lower clause in a Q-marking construction are identical to those of other question-word questions, taking into consideration the shape of any pitch accent present and the overall tonal contour (in line with the indirect dependency analysis).

H3: The Q-marking construction's intonation is not consistent with a direct relationship existing between the Q-marker and the question word(s) in the lower clause. It is consistent only with an indirect relationship linking the Qmarker to the entire lower clause containing the question word(s).

For the sake of clarity, it will be important in this paper to be able to distinguish the question phrases in lower clauses whose scope is extended by the presence of a Qmarker from the Q-marker element itself. At the same time, any premature judgements about the status of the Q-marker, either implicit or explicit, are to be avoided given that this is an issue which this study seeks to explore. To this end, I shall henceforth refer to 
the question phrases whose scope is extended by the presence of a Q-marker as associated question phrases. This terminology is designed to be neutral with respect to the issue of whether the Q-marker is in fact a question word itself.

\section{SPEECH DATA: METHODOLOGY, ANALYSIS}

The same approach to elicitation was adopted for spoken Hungarian and Slovenian data in this study. Examples of non-spontaneous speech were elicited from native speakers at a minimum of three separate recording sessions held at the Kempelen Farkas Speech Research Laboratory at the Research Institute for Linguistics of the Hungarian Academy of Sciences in Budapest, Hungary, and at the University of Ljubljana, Slovenia. None of the consultants reported any speech or hearing difficulties. Sessions were non-consecutive and each one was divided into smaller sub-sessions. Recordings were made using a Stagg CM-5050 electret-condensor microphone and a Marantz PMD670 solid-state recorder. The recordings were made in mono, with a sampling rate of $48 \mathrm{kHz}$ and a constant bit rate of $768 \mathrm{kbps} / \mathrm{ch}$. The audio files created were saved in .wav format.

Consultants were asked to read aloud single sentences and question-and-answer (two-sentence) dialogues at each recording session. Target sentences/dialogues were presented in pseudo-randomized order printed on cards. Written instructions were presented before each session which requested that the consultants read the material fluently at a natural speed and volume, as if they were speaking with a friend. Each consultant produced the single-sentence stimuli during separate sub-sessions, at which they were recorded individually. For the dialogues, two speakers were recorded together at a different sub-session. Both consultants read the question and the answer before they 
spoke. They were instructed to ask each question as if they genuinely did not know the answer in order to minimize the possibility of eliciting echo questions. The QWQs in the dialogues were of various types: they consisted of single or multiple clauses, and contained single or multiple questions words which took matrix scope or embedded scope. In most cases, the question words included were human (i.e. who) in order to control for the animacy of the arguments involved when they co-occurred in a multiple QWQ. The sentences were designed to exclude obstruents as far as possible, as these are known to affect $F_{0}$ in adjoining pitch periods. It is well known that obstruents can perturb pitch and this should be borne in mind when viewing pitchtracks: as Hayes \& Lahiri (1991: 58) point out, 'pitch is [often] lowered just before a voiceless obstruent, and raised just after it'. In addition 'voiced obstruents [often] lower pitch'. However, it was not always practicable to exclude such sounds. For example, question words for humans in both Hungarian and Slovenian begin with an obstruent.

Target sentences were extracted from the original recordings and saved as separate files. Pitch contours and $\mathrm{F}_{0}$ values, measured in $\mathrm{Hz}$, were obtained using Praat (Boersma \& Weenink 2018). In each case, utterances were segmented into words and labelled with information about tones and boundaries. For each sentence type in each language, a general pattern of intonation was identified and verified by consulting native-speaker linguists in conjunction with such impressionistic accounts of the relevant intonation patterns and results of experimental work as are available in the literature. The pitchtracks provided in this paper represent one utterance produced by a single consultant on one occasion that exemplifies this intonation pattern for each of the target constructions. 


\subsection{Representing intonational structure}

This work documents, describes, and compares the intonation of the Q-marking construction in two different languages for the first time. One of my aims is to make my findings broadly accessible, so I seek to capture generalizations about intonation patterns in as theory-neutral a way as possible in this paper.

Following much work on the analysis of intonation (Pierrehumbert 1980; Pierrehumbert \& Beckman 1988; Hayes \& Lahiri 1991; Gussenhoven 2004; the papers in Jun 2005, 2014; Ladd 2008; inter alia), intonation contours are expressed in terms of two tones: $\mathrm{H}(\mathrm{igh})$ and $\mathrm{L}(\mathrm{ow})$. By combining these two tones, it is possible to represent more complex tonal events. For example, a bitonal rising pitch accent can be represented using the plus sign as $\mathrm{L}+\mathrm{H}$, and a bitonal falling pitch accent as $\mathrm{H}+\mathrm{L}$. Intonation contours are abstract tunes composed of these tonal specifications.

A single tune can be associated with different texts, where the term 'texts' refers to actual strings of words (sequences of segments). In order to specify relevant aspects of tune-text association in this paper, it is necessary to distinguish between pitch accents and boundary tones. Pitch accents associate with stressed syllables within a domain; boundary tones associate with the left or right edge of a domain. Defining intonational domains has been the focus of a great deal of research and discussion in the literature. Precisely which units should be used to analyse intonational structure above the level of the syllable in a language continues to be the subject of debate. For the purpose of this study, I will simply define the relevant intonation contours in terms of their principal characteristic boundary tones and pitch accents, specifying how tune is associated with text in each case. Boundary tones will be denoted by an additional $\beta$, which will appear before the relevant tone if the boundary tone is associated with the left edge (for 
example, $\beta \mathrm{H}$ ) or after it if the boundary tone is associated with the right edge (for example, $H \beta)$. In this way, I seek to capture the essential features of the relevant intonation contours in the two case-study languages in a way that is succinct and insightful without making claims about the existence of certain prosodic units in either language, and while simultaneously being generally accessible and facilitating crosslinguistic comparison.

\section{QUESTION FORMATION AND INTONATION IN HUNGARIAN}

\subsection{Syntax}

Hungarian is a member of the Finno-Ugric language family. It is regarded as a classic discourse configurational language: certain syntactic positions are associated with discourse functions such as topic and focus rather than grammatical functions like subject and object, which are instead indicated via the language's rich system of inflectional morphology. The key facts about word order are captured by the generalization in (10), where the Kleene star indicates that an element may occur zero or more times and brackets indicate optionality.

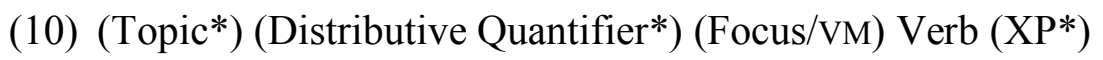

Apart from nem 'not', nothing can separate the Focus constituent from the verb, not even a verbal modifier (VM), an element which often accompanies a verb in this language. Verbal modifiers include items with directional or aspectual meaning (for instance fel 'up' in example 11), amongst others (see, e.g., É. Kiss 2002, Laczkó 2014, for details). When a Focus item is present, any VM appears immediately after the verb 
rather than preverbally, as illustrated in (11a). This is not the case when a topic (11b) or a distributive quantifier (11c) appears before the verb, making the position of vM a useful diagnostic for Focus. ${ }^{5}$ When the vM precedes the verb, it forms a single prosodic word with the verb, as reflected in the orthography.

(11) (a) [János $]_{\text {TOPIC }}[\text { Mari-t }]_{\text {FOCUS hívta fel }}$ János.NOM Mari-ACC called.3SG VM 'János called MARI.'

(b) [János $]_{\text {TOPIC }}$ fel-hívta Mari-t.

János.NOM VM-called.3SG Mari-ACC

'János called Mari.’

(c) $[\text { János }]_{\text {TOPIC }}[\text { mindenki-t }]_{\text {Distrib.Quant. }}$ fel-hívott.

János.NOM everyone-ACC VM-called.3SG

'János called everyone.'

In what I shall refer to as a QWQ (a question-word question), a question phrase occupies preverbal position (12), just as a non-interrogative Focus constituent does in Hungarian.

(12) [János $]_{\text {TOPIC }}$ ki-t mutatott be Annának?

János.NOM who-ACC introduced.3SG VM Anna.DAT

'Who did János introduce to Anna?' 
Multiple preverbal question phrases in a Hungarian QWQ form an indivisible group immediately before the verb.
(13)
[János] $]_{\text {Tоріс }}$ ki-t ki-nek mutatott be?
János.NOM who-ACC who-DAT introduced.3SG VM
'Who did János introduce to who?'

Thus, Hungarian can be classed as a multiple-fronting language if we take fronting to mean displacement rather than displacement specifically to clause-initial position. ${ }^{6}$

In a QWQ when a question phrase takes scope over a clause higher than the one in which it bears a grammatical function, the question phrase appears in that higher clause, just as in English. As was the case in a single-clause question, the question phrase appears immediately preverbally in the higher clause in Hungarian:

(14) István ki-nek gondolja, [hogy János be-mutatta István.NOM who-DAT think.3SG that János.NOM VM-introduced.3SG Mari-t]?

Mari-ACC

'Who does István think that János introduced Mari to?'

This QWQ formation strategy is available only when a single question phrase appears in (and therefore takes scope over) a higher clause. The result of multiple fronting, 
equivalent to that employed to form a single-clause question such as (13), is ungrammatical (Puskás 2000: 262). If multiple question phrases are to take scope over a higher clause, the Q-marking construction discussed in Section 4.3 is required instead of a QWQ-type construction.

\subsection{Intonation}

The spoken Hungarian data presented and discussed in this paper represent the variety used by speakers from Budapest. The consultants were four native speakers of Hungarian, two males and two females, aged between 20 and 35, who were all born and raised in the Budapest area.

Kálmán (1985a, b) distinguishes between neutral and non-neutral Hungarian sentences, which differ in terms of the intonation contours that they bear. Kálmán defines non-neutral sentences as those that include some sort of operator (for instance, a constituent in Focus position or a distributive quantifier, etc.) and describes them as being ‘fairly marked semantically’ (Kálmán et al. 1986: 130), whereas neutral sentences do not include such a constituent. Neutral sentences are neither emphatic nor corrective.

\subsubsection{Neutral declarative intonation}

Neutral sentences are described in Kálmán (1985a, 1985b), Kálmán et al. (1986), and Varga (2002: 140) as being level, in that each word has equal prominence. Declination (decrease in pitch values) applies to give a sequence of downsteps, forming a 'descending staircase' pattern: 
(15) János be-mutatta Mari-t Annának a mozi-ban.

János.NOM VM-introduced.3SG Mari-ACC Anna.DAT the cinema-INE

'János introduced Mari to Anna at the cinema.'

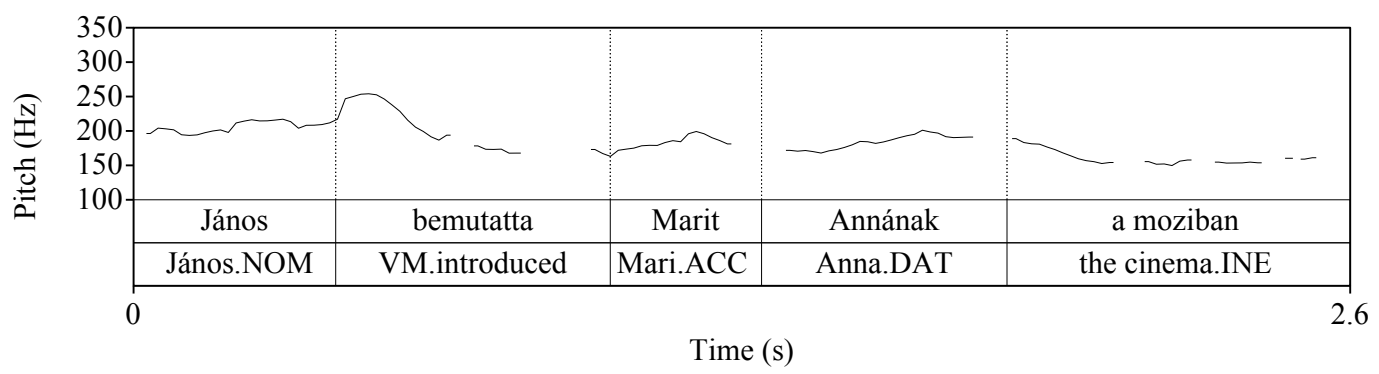

Szendrői (2001) and É. Kiss (2002), by contrast, claim that a single main stress is assigned in such sentences. As (15) is provided only for the purposes of comparison with utterances that exhibit non-neutral intonation, the precise analysis of neutral intonation is set aside.

\subsubsection{Non-neutral intonation}

The intonation of non-neutral sentences, which contain at least one operator (Kálmán 1985b; Kálmán et al. 1986), has certain defining characteristics. It minimally comprises a falling pitch accent $(\mathrm{H}+\mathrm{L})$ connected by a low plateau to a final boundary tone, $\mathrm{L} \beta$ (see Mycock 2010a, b). ${ }^{7}$ The utterance in (16) is a non-neutral sentence. It contains an operator: the constituent Annának 'Anna' appears in the immediately preverbal Focus position (as indicated by the post-verbal position of the verbal modifier be; see Section 4.1). This sentence also includes a topic, János. The topic has its own separate intonation contour (see Rosenthall 1992, Genzel et al. 2015, Mády 2015). The distinct topic intonation contour is not a concern of this paper and will be set aside in what follows. 


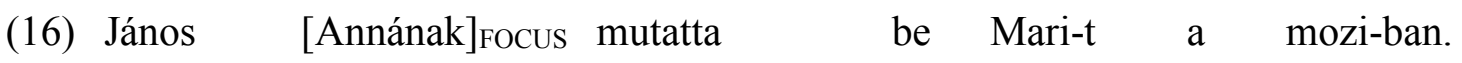

János.NOM Anna.DAT introduced.3SG VM Mari-ACC the cinema-INE

'János introduced Mari to ANNA at the cinema.'

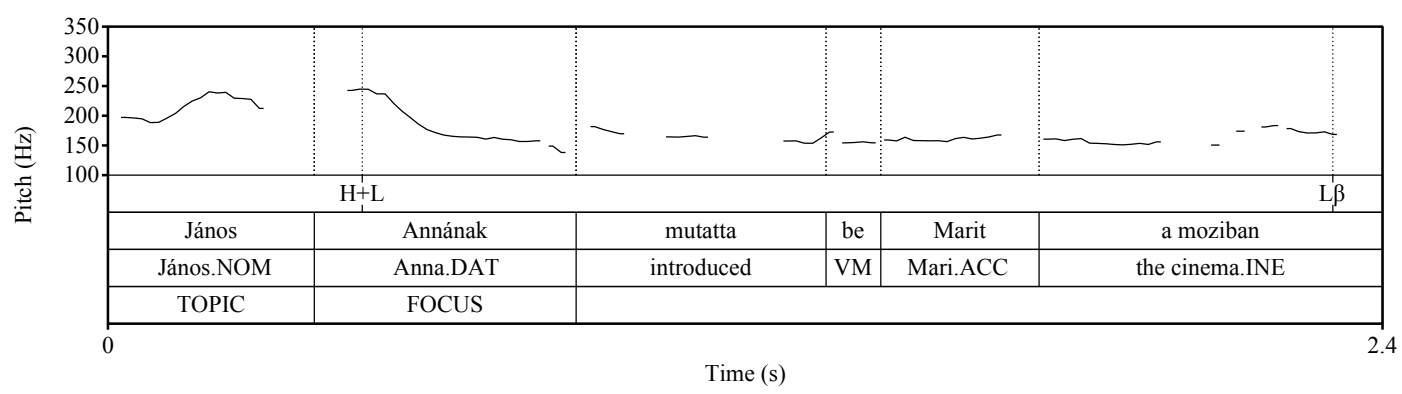

Any QWQ represents an example of a non-neutral sentence because it includes a 'wh'-operator - a question word - and will exhibit the characteristic features of the associated pitch contour, i.e. H+L L $\beta$. As (17) shows, the question word bears the characteristic falling pitch accent $(\mathrm{H}+\mathrm{L})$ followed by a low plateau extending to a final low boundary tone (L $\beta)$.

(17) János

ki-nek mutatta be Mari-t?

János.NOM who-DAT introduced.3SG VM Mari-ACC

'Who did János introduce Mari to?'

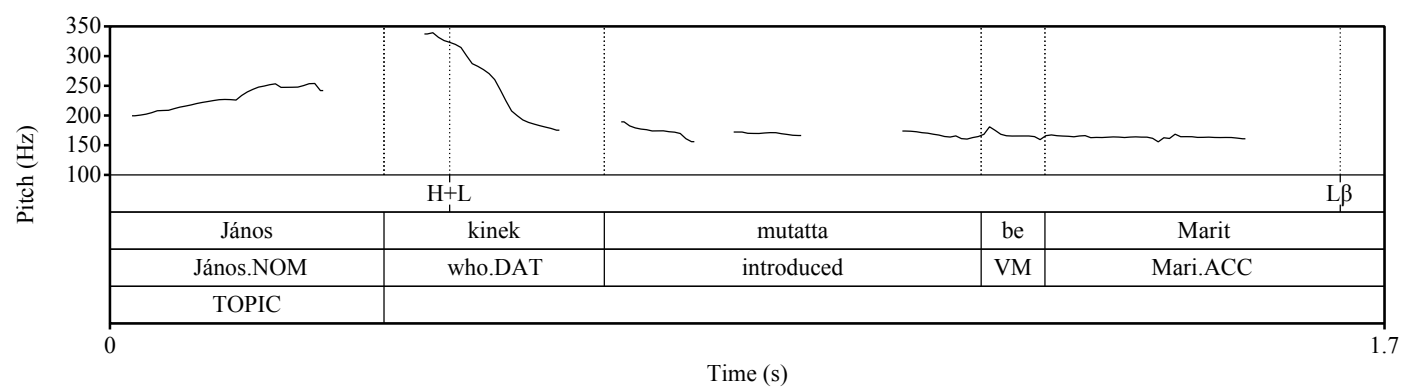


This same combination of falling pitch accent and low final boundary tone is attested regardless of whether the question phrase appears in the same clause in which it bears a grammatical function or a higher one, as (18) illustrates. (18) is a matrix question; that is, the question word (kinek) takes scope over the matrix clause so the whole sentence is a question. As well as the location of the question word in the matrix clause, the sequence of a fall followed by a low plateau $(H+L \quad L \beta)$ is an indicator of the extent of interrogative scope (how much of the sentence is a question; this is represented by underlining in 18), stretching as it does in a matrix multi-clause question from the question word over the entire subordinate clause. In this respect, interrogative scope is encoded in the syntax and intonationally.

(18) István ki-nek gondolja, [hogy János be-mutatta

$$
\underline{\mathrm{H}+\mathrm{L}}
$$

István.NOM who-DAT thought.3SG that János.NOM VM-introduced.3SG

Mari-t]?

$\mathrm{L} \beta$

Mari-ACC

'Who does István think that János introduced Mari to?'

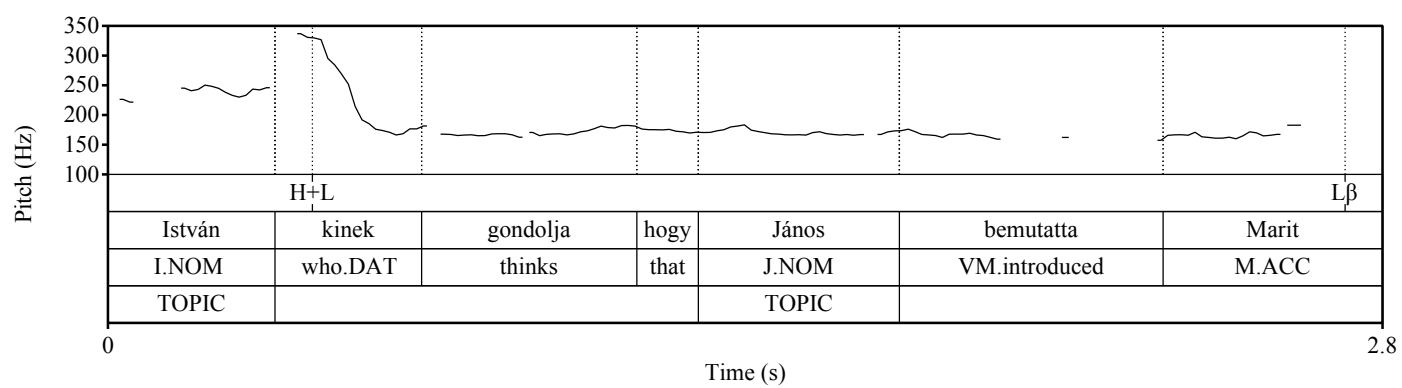


When multiple question words are present, it is the final question word in the immediately preverbal group that bears the falling pitch accent characteristic of the nonneutral tune (Mycock 2010a). Preceding question words form a high plateau, indicating the presence of an initial boundary tone $(\beta \mathrm{H})$ before the falling $(\mathrm{H}+\mathrm{L})$ pitch accent. ${ }^{8}$ This is the case no matter how many question words appear preverbally or what order they appear in relative to one another (Mycock 2010a, b). For instance:

(19) $\mathrm{Ki}$

ki-t ki-nek mutatott be?

who.NOM who-ACC who-DAT introduced.3SG VM

'Who introduced who to who?'

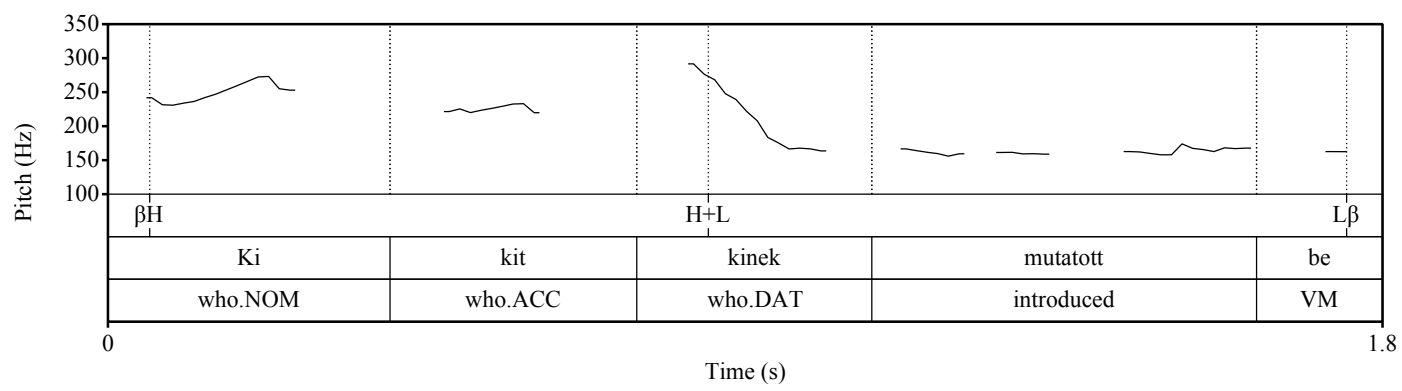

(20) Ki-nek ki-t ki mutatott be?

who-DAT who-ACC who.NOM introduced.3SG VM

'Who introduced who to who?'

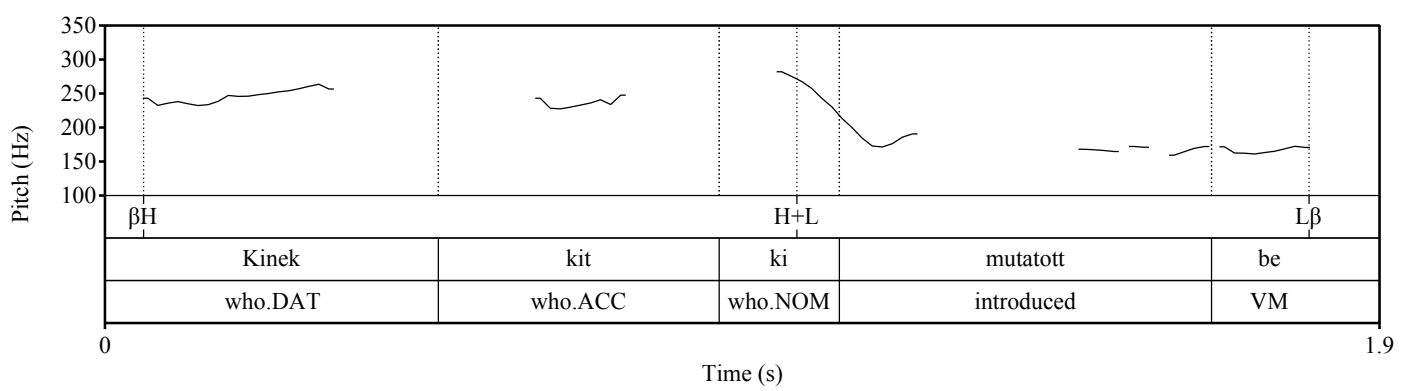


I therefore analyse the tune used with a multiple QWQ as commencing with a $\beta \mathrm{H}$ boundary tone (see also Mycock 2010a, b; Gyuris \& Mády 2013; and Mády \& Szalontai 2014).

In summary, Hungarian QWQs are associated with the non-neutral intonation contour: there is an optional initial $\beta \mathrm{H}$ boundary tone before the pitch accent $\mathrm{H}+\mathrm{L}$, and the tune ends with a $\mathrm{L} \beta$ boundary tone. The falling pitch accent $(\mathrm{H}+\mathrm{L})$ is realized on the only or final question word in the immediately preverbal question-phrase group. The low plateau extends from the matrix clause over the subordinate clause(s) in the case of a matrix question, coinciding with the scope of the question phrase in the higher clause.

\subsection{The Q-marking construction}

In this section, I present data that illustrate the intonation contour associated with the Qmarking construction. In light of these data, I consider the three hypotheses in Section 2 concerning pitch accent, tonal contour, and the relationship between the Q-marker and the lower clause containing the associated question word(s) in the Q-marking construction.

As Mycock (2010b) outlines, Hungarian Q-marking constructions share certain intonational properties with QWQs and other non-neutral sentences in Hungarian, i.e. a $\mathrm{H}+\mathrm{L}$ pitch accent followed by a low plateau. What is different is that this tune is attested in BOTH the clause containing a Q-marker AND the lower clause that includes the associated question phrase, consistent with each tune's left edge aligning with a scope-taking element. As (21) shows, the consecutive tunes form a chain, linking the Qmarker to the associated question phrase in the lower clause. The extent of the entire Qmarking intonation pattern is an indicator of the extent of interrogative scope - it starts in a higher clause and continues until the end of the question, coinciding with the 
information about the extent of interrogative scope encoded in the syntax via the position occupied by the Q-marker. The intonational scope-marking associated with the Q-marking construction differs from that associated with a QWQ such as (18) in being complex, comprising multiple QWQ tunes each associated with a different scope-taking element rather than a single QWQ tune as in (18). (Underlining indicates each instance of the relevant tune.)

(21) István

mi-t

gondol, [hogy János

ki-nek mutatta

$\underline{\mathrm{H}+\mathrm{L}}$ $\mathrm{L} \beta$

$\underline{\mathrm{H}+\mathrm{L}}$

István.NOM QM-ACC thinks.3SG that János.NOM who-DAT introduced.3SG be Mari-t]?

$\mathrm{L} \beta$

VM Mari-ACC

'Who does István think that János introduced Mari to?'

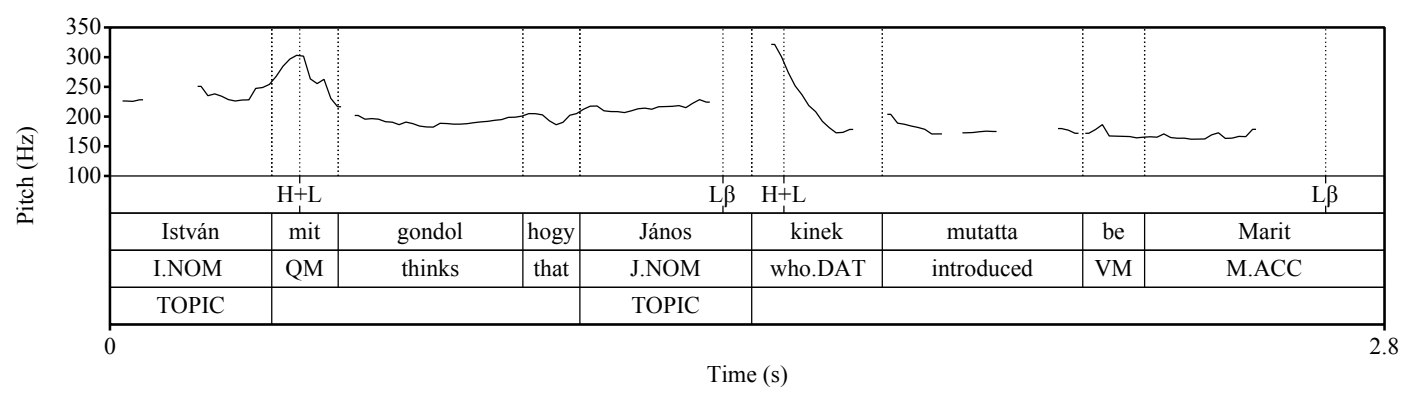

The Q-marker and the associated question phrase in (21) both bear a $\mathrm{H}+\mathrm{L}$ pitch accent. The low plateau following the fall on the Q-marker in (21) includes both hogy 'that' and János (i.e. the sequence of complementizer and topic) in the lower clause. This is clear when we compare the Q-marking construction in (21) with (22), which is an example of an embedded question, so a question in which interrogative scope extends only over the 
subordinate clause (the sentence is a declarative). Notice that János in (22) bears an identifiable rise followed by a slight fall consistent with the typical rise(-fall) topic contour (Rosenthall 1992; Section 3.2.2). This is not the case in (21), where János is part of the low plateau following the fall on the Q-marker mit. The end of this low plateau is pulled upwards slightly in (21), but this is due to the $\mathrm{H}+\mathrm{L}$ accent borne by the associated question phrase kinek 'who' which follows it.

(22) István

meg-kérdezte, [hogy János

ki-t hívott fel].

$\underline{\mathrm{H}+\mathrm{L}}$ $\mathrm{L} \beta$

István.NOM VM-asked.3SG that János.NOM who-ACC called.3SG VM

'István asked who János called.'

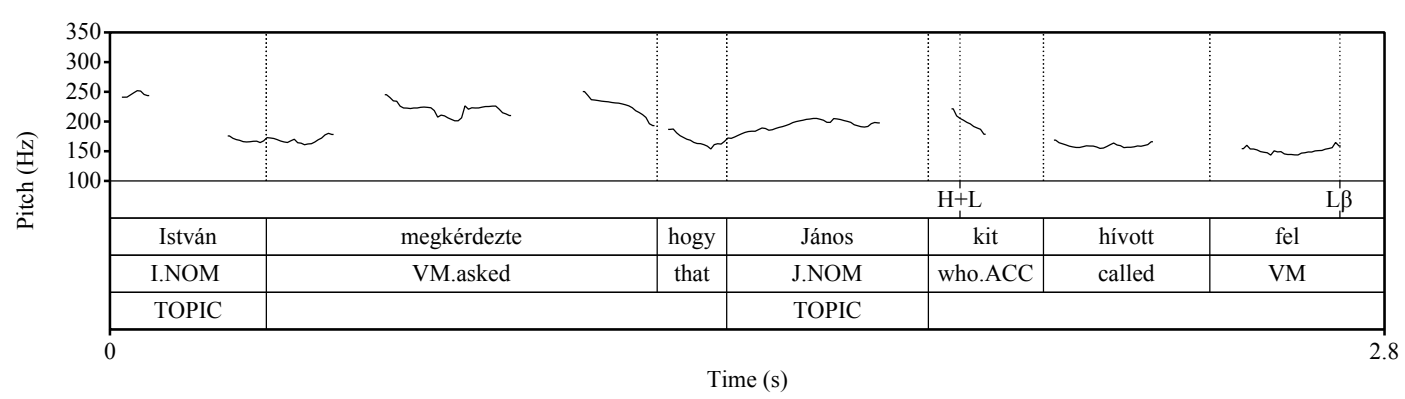

The same basic pattern of intonation is present when multiple Q-markers - one per clause - are used to extend the scope of an associated question phrase, as (23) reveals. Again, the low plateau following each $\mathrm{H}+\mathrm{L}$ pitch accent borne by a Q-marker extends over the start of each lower clause up to either the next Q-marker (mit) or an associated question phrase (kit in 23). 
(23) István

mi-t gondol, [hogy Ilona mi-t akar,
$\underline{\mathrm{H}+\mathrm{L}}$
$\mathrm{L} \beta$
$\underline{\mathrm{H}+\mathrm{L}}$

István.NOM QM-ACC think.PRS.3SG that Ilona.NOM QM-ACC want.PRS.3SG

[hogy János ki-t hív-j-on fel]]?

$\mathrm{L} \beta \quad \mathrm{H}+\mathrm{L} \quad \mathrm{L} \beta$

that János.NOM who-ACC call-SBJV-3SG VM

'Who does István think that Ilona wants János to call?'

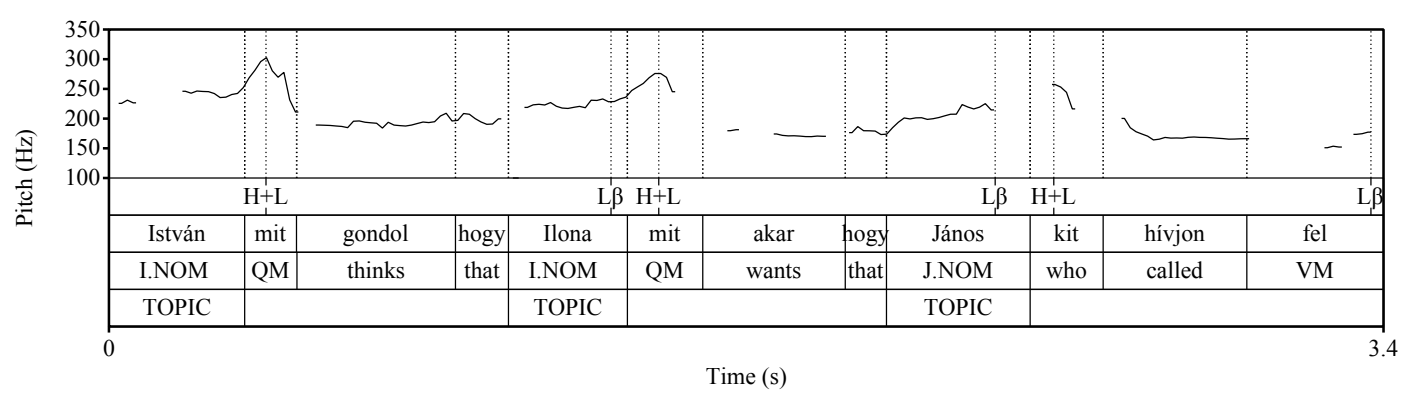

When the lower clause in a Q-marking construction contains multiple question words, the same intonational pattern is attested: in (24) the complementizer hogy and the non-final question word $k i$ are part of the low plateau that is pulled upwards at its end as the $\mathrm{H}+\mathrm{L}$ pitch accent on the final associated question word kit approaches; compare, for example, the slight rises towards the end of Ilona and János in (23) and ki 'who' in (24). This example shows that non-final question words are comparable to their non-interrogative counterparts in this respect.

(24) István

$$
\begin{array}{lrrrrr}
\text { mi-t } & \text { gondol, } & {\left[\begin{array}{ll}
\text { hogy } \\
\text { ki }
\end{array}\right.} & \text { ki-t } & \text { hívott } & \text { fel]? } \\
\mathrm{H}+\mathrm{L} & \mathrm{L} \beta & \underline{\mathrm{H}+\mathrm{L}} & \mathrm{L} \beta
\end{array}
$$

István.NOM QM-ACC thinks.3SG that who.NOM who-ACC called.3sG VM

'Who does István think called who?' 


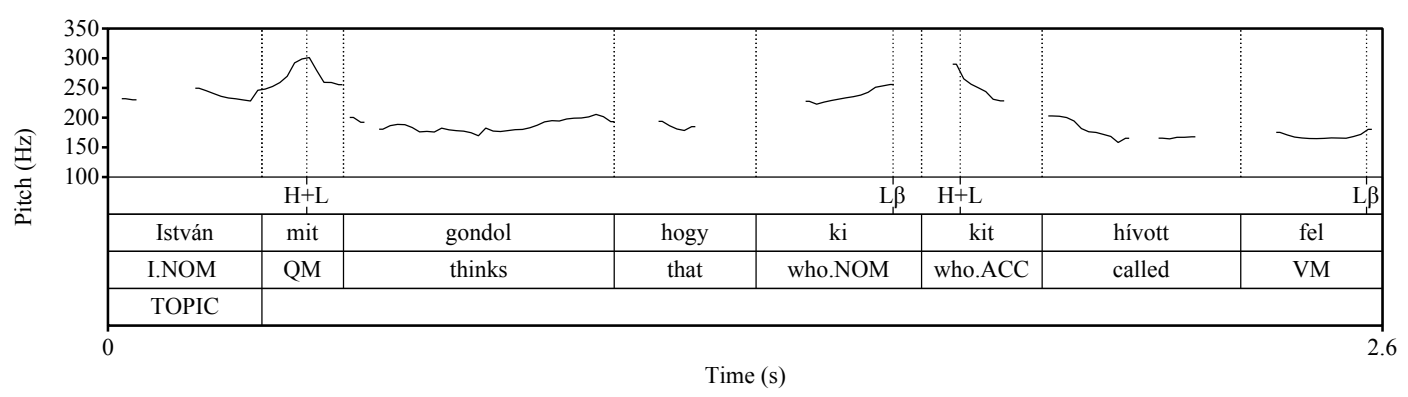

As in Hungarian QWQs, the extent of interrogative scope is encoded by both syntax and intonation in the Q-marking construction. The extended scope of an associated question phrase is encoded syntactically by the position of a Q-marker, which simultaneously represents the beginning of the Q-marking tune (intonational encoding).

We can summarize the intonation patterns of QWQs and the Q-marking construction as shown in Table 1.

\begin{tabular}{ll}
\hline Sentence type & Tune \\
\hline QWQ & $(\beta \mathrm{H}) \mathrm{H}+\mathrm{L} \mathrm{L} \beta$ \\
(pitch accent on immediately preverbal question word) & \\
\hline $\begin{array}{l}\text { Q-marking construction } \\
\text { (first pitch accent on a Q-marker, final pitch accent on the }\end{array}$ & $\mathrm{H}+\mathrm{L}$ L $\beta$ H+L L $\beta$ \\
immediately preverbal associated question word) & \\
\hline
\end{tabular}

Table 1

Characteristic intonation patterns of QWQs and the Q-marking construction in Hungarian

With respect to the three hypotheses stated at the end of Section 2 (each summarized below for ease of reference), the following conclusions can be drawn about the Q-marking construction in Hungarian.

H1: Q-markers and question words bear the same pitch accent (consistent with the indirect dependency analysis). 
CONCLUSION: Q-markers bear the same pitch accent $(\mathrm{H}+\mathrm{L})$ as other operators including question words, in line with both the indirect and direct dependency analyses. ${ }^{9}$

While it is true that Q-markers and question words bear the same pitch accent, it is important to recognise that this does not mean that the intonation facts support only an analysis which treats a Q-marker as being a question word. The alternative is that a Qmarker is an expletive element included only in order to extend the scope of associated question phrases. All operators bear the same $\mathrm{H}+\mathrm{L}$ pitch accent in Hungarian, and this includes not only interrogative but also non-interrogative constituents in immediately preverbal Focus position; see, for instance, (16). Given their definitional lack of semantic content, it may seem inherently contradictory to propose that the Q-marker is an expletive with focus status, but focus expletives do exist - Lecarme (1999), for example, identifies a focus expletive in Somali - and this analysis has been proposed for the Q-marker in Hungarian (Kenesei 1998b). The intonational properties of the Qmarker in Hungarian are consistent with it being either a question word (indirect dependency analysis) or a scope-extending expletive (direct dependency analysis).

H2: The lower clause in a Q-marking construction has exactly the same intonational properties as a QWQ.

CONCLUSION: The lower clause in a Q-marking construction displays many but not all of the intonational characteristics of a QWQ; they are not identical.

The same basic (non-neutral) intonation pattern is found in QWQs and Q-marking constructions. In a Q-marking construction, there are multiple occurrences of the relevant tune $(\mathrm{H}+\mathrm{L} \mathrm{L} \beta)$. These tunes appear consecutively, with the low plateau following the $\mathrm{H}+\mathrm{L}$ pitch accent borne by a Q-marker ceasing only when the final/sole associated question phrase (or, alternatively, another Q-marker) in immediately 
preverbal Focus position in a lower clause is reached; see, for instance (21), (23), (24). In this respect, the intonational link in a Q-marking construction appears to be between a Q-marker and an associated question phrase, rather than between a Q-marker and the lower clause as a whole because the low plateau extends across the clause boundary. In the Hungarian Q-marking construction, the boundaries of syntactic units and the domains of intonational contours do not align. This brings us to the final hypothesis to be tested.

H3: The Q-marking construction's intonation is consistent only with a relationship existing between a Q-marker and the entire lower clause containing the associated question phrase(s) (indirect dependency analysis) and NOT between a Q-marker and the associated question phrase(s) in a lower clause (direct dependency analysis).

CONCLUSION: The Q-marking construction's intonation is consistent with a direct relationship existing between a Q-marker and an associated question phrase in a lower clause.

To be precise, the relevant relation crucially involves a Q-marker and ONE associated question phrase - the one that appears in the immediately preverbal Focus position. This is consistent with the type of direct dependency proposed in McDaniel (1989), according to which 'two or more Wh-phrases [question phrases] with the same scope are members of one Wh-chain'. This 'wh'-chain has a head. The presence of the head delimits interrogative scope, i.e. the scope of all members of the 'wh'-chain. In a Q-marking construction the head of the 'wh'-chain is a Q-marker (an expletive element whose function is to extend the scope of one or more associated question phrases ${ }^{10}$ under McDaniel's analysis). The intonation of the Hungarian Q-marking construction 
provides support for McDaniel's chain proposal and her direct dependency analysis, according to which there is a direct relationship between Q-markers and associated question words because an intonational 'chain' of QWQ tunes links the scope-taking elements (Q-markers, associated question phrases) in a Q-marking construction. Taken as a whole, the series of intonation contours initiated by the pitch accent on the first/only Q-marker indicates the total extent of interrogative scope in a Hungarian Qmarking construction.

\section{QUESTION FORMATION AND INTONATION IN SLOVENIAN}

Slovenian is a South Slavic language which 'by European standards is still somewhat under-described' (Marušič \& Žaucer 2006: 155). For this reason, it is necessary to devote relatively more space in this paper to Slovenian compared to the other case-study language, Hungarian.

\subsection{Syntax}

Slovenian word order appears to be flexible if only the grammatical functions of constituents (subject, direct object, etc.) are considered. As with Hungarian, grammatical functions are indicated via a rich system of inflectional morphology, though this system is far less complex than the Hungarian one. Slovenian is a Wackernagel language: clitics form a group with a strict internal order which appears in second position (P2) after the first syntactic constituent in a sentence (Bennett 1986; Franks \& King 2000; Marušič 2007). Slovenian clitics are prosodically neutral: they can be enclitic or proclitic (Bennett 1986; Franks \& King 2000: 41). Only when there is unambiguous evidence for the direction of cliticization will it be indicated in the examples presented in this paper. 
A Slovenian question-word question includes at least one question phrase in clauseinitial position; note the position of the auxiliary clitic je in $\mathrm{P} 2$ in (25). As the response sentence in (25) shows, an 'answer constituent' such as Heleni 'Helena' need not appear in clause-initial position - or in fact any one particular position - in a declarative.

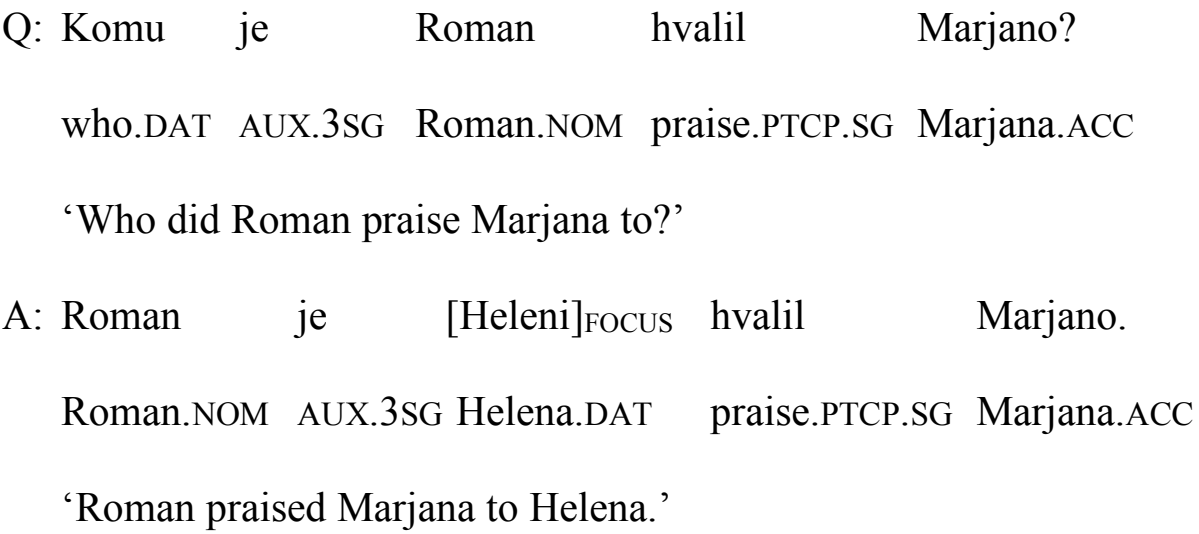

When multiple question phrases are present in a single-clause question, they appear at the beginning of the sentence, making Slovenian a multiple-fronting language. ${ }^{11}$ If any P2 clitics are present, they separate the first question phrase from the others, as shown in (26); all question phrases are fronted, but the requirement for clitics to appear in P2 after the first syntactic constituent must be respected.

(26) (a) Kdo je koga komu hvalil? who.NOM AUX.3SG who.ACC who.DAT praise.PTCP.SG 'Who praised who to who?' 
(b) Koga je kdo komu hvalil?

who.ACC AUX.3SG who.NOM who.DAT praise.PTCP.SG

(c) Komu je kdo koga hvalil?

who.DAT AUX.3SG who.NOM who.ACC praise.PTCP.SG

Turning next to multi-clause questions, a single question phrase may appear in initial position in a clause higher than the one in which it bears a grammatical function, with this higher clause being the one over which it takes scope. This is directly comparable to Hungarian QWQ formation, as illustrated in (14). ${ }^{12}$

(27) Koga je Miha mislil, $[\mathrm{da}$ je
who.ACC AUX.3SG Miha.NOM think.PTCP.SG that AUX.3SG Roman.NOM
hvalil Heleni]?
praise.PTCP.SG Helena.DAT
'Who did Miha think Roman praised to Helena?'

Marušič (2008: 413) reports that in a Slovenian QWQ 'only one wh-word can move out of an embedded finite clause' to initial position in a higher clause. ${ }^{13}$ The Qmarking construction, an alternative to multiple fronting as Hungarian has shown (Section 4.3), is also used in Slovenian; details are provided in Section 5.3.

To summarize, Slovenian exhibits multiple fronting of question phrases in singleclause questions, but in a multi-clause QWQ only one question word can be fronted to initial position. The preferred strategy when multiple question phrases take scope over a higher clause is the Q-marking construction. Slovenian, despite being unrelated and 
typologically distinct in many respects, is therefore very similar to Hungarian when it comes to the formation of questions including question phrases.

\subsection{Intonation}

The spoken data presented and discussed in this paper represent examples of Standard Slovenian. Speech data were elicited from four female native speakers, all born and raised in Ljubljana and aged in their thirties. ${ }^{14}$

As with Hungarian (Section 4.2), it is possible to distinguish between neutral declarative intonation and non-neutral intonation in Slovenian.

\subsubsection{Neutral declarative intonation}

Data collected for this study indicate that a neutral declarative utterance ends in a fall $\mathrm{CH}$ L $\beta$ ) with the pitch accent $(\mathrm{H})$ located on the last accented word, consistent with Toporišič's (1984: 456) description of this tune.

(28) Roman=je

Heleni hvalil

Marjano.

Roman.NOM=AUX.3SG Helena.DAT praise.PTCP.SG Marjana.ACC

'Roman praised Marjana to Helena.'

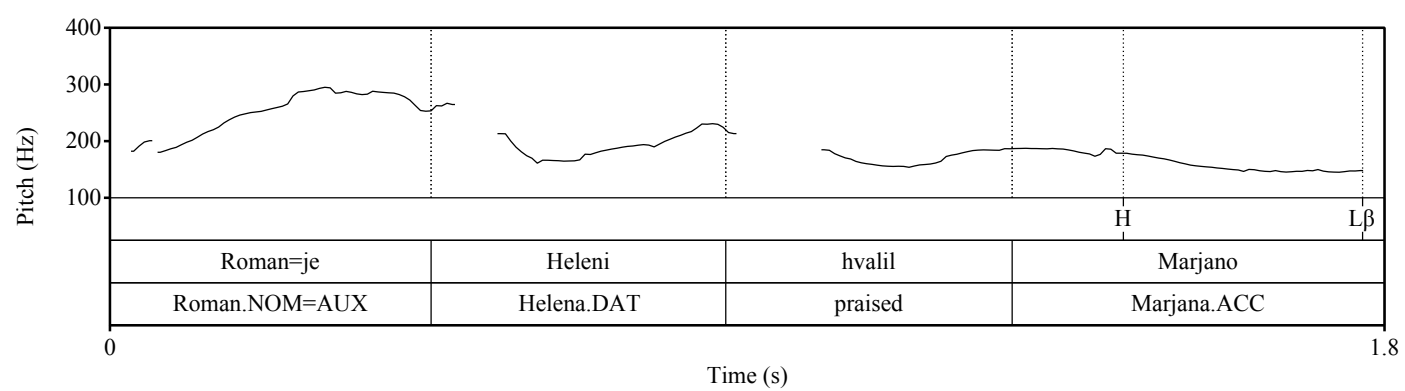

That a final fall is characteristic of a Slovenian declarative rather than being associated

with a specific lexical item can be shown by having another word appear in final 
position. Slovenian has flexible word order so as well as (28), (29) is possible. In sentence-final position in (29), Heleni clearly bears the final fall.

(29) Marjano=je

Roman hvalil

Heleni.

Marjana.ACC=AUX.3SG Roman.NOM praise.PTCP.SG Helena.DAT

'Roman praised Marjana to Helena.'

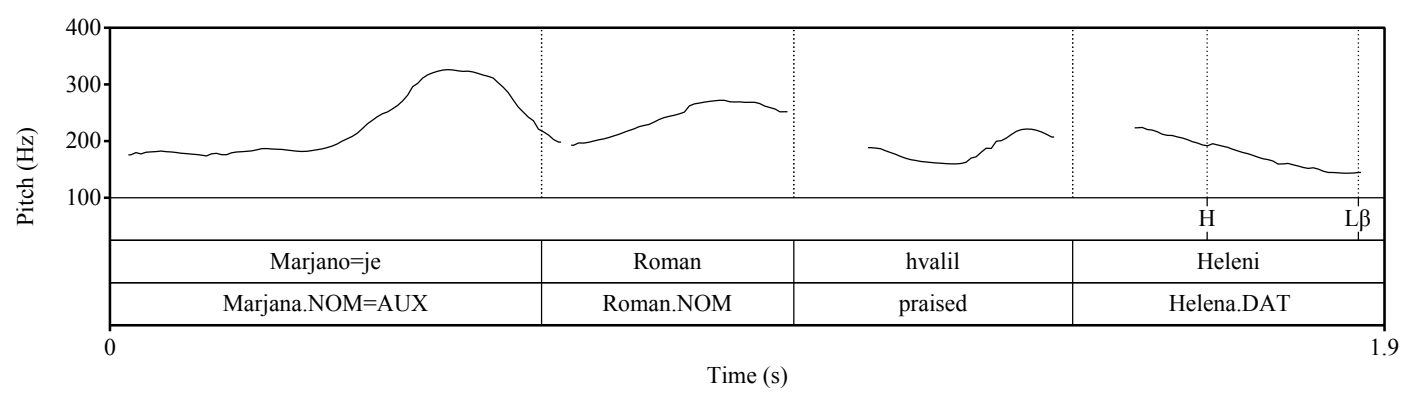

The same basic pattern of neutral declarative intonation is found in examples comprising multiple clauses:

(30) Miha=je

$$
\text { mislil }=[\mathrm{da}=\mathrm{je}
$$

Roman

Heleni

Miha.NOM=AUX.3SG think.PTCP.SG=that=AUX.3SG Roman.NOM Helena.DAT

hvalil Marjano].

praise.PTCP.SG Marjana.ACC

'Miha thought that Roman praised Marjana to Helena.'

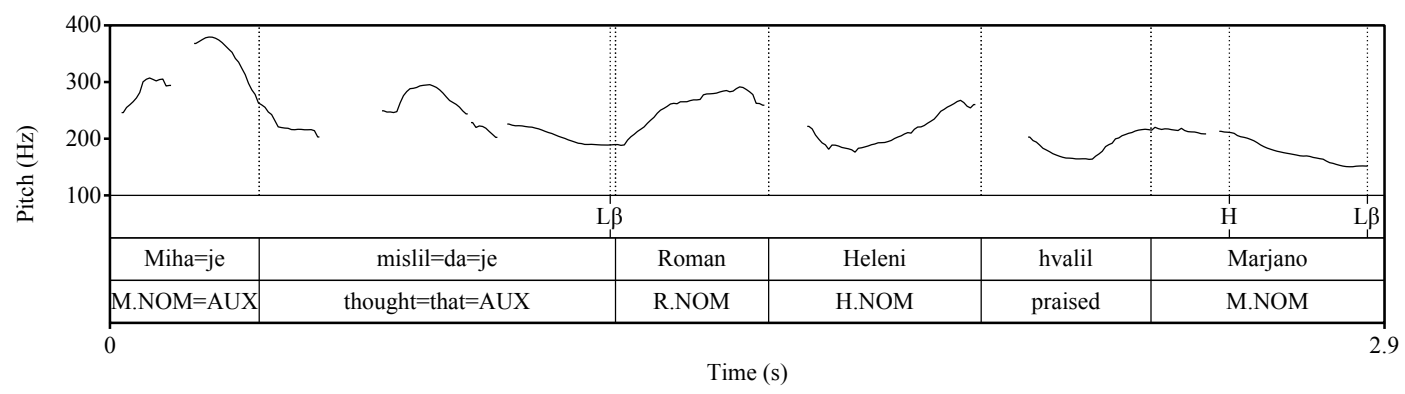


(31) Miha $=\mathrm{je}$

mislil $=[\mathrm{da}=\mathrm{je} \quad$ Manuela

Miha. $\mathrm{NOM}=\mathrm{AUX} .3 \mathrm{SG}$ think.PTCP.SG $=$ that $=$ AUX.3SG Manuela.NOM

rekla $=[\mathrm{da}=\mathrm{je} \quad$ Roman Heleni hvalil

say.PTCP.SG=that=AUX.3SG Roman.NOM Helena.DAT praise.PTCP.SG

Marjano]].

Marjana.ACC

'Miha thought that Manuela said that Roman praised Marjana to Helena.'

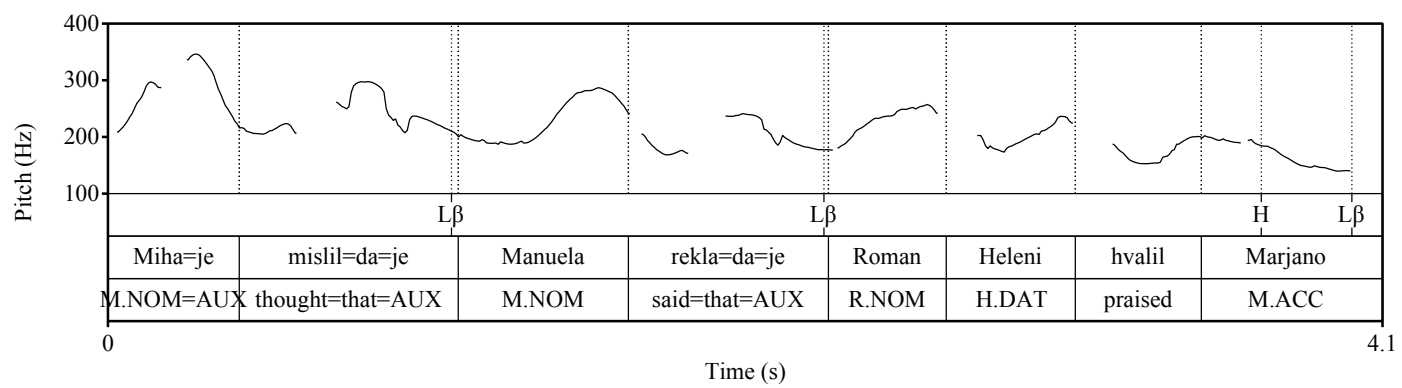

The other noteworthy feature of multi-clause sentences like (30) and (31) is that a L $\beta$ boundary tone follows each embedding verb plus any clitic cluster attached to it ( mislil $=d a=j e$, rekla $=d a=j e)$.

In summary, the data elicited for this study support Toporišič's (1984) description of neutral declarative intonation in Slovenian as ending in a final fall. This tune is composed of a pitch accent $\mathrm{H}$ located on the final word followed by a final L $\beta$ boundary tone.

\subsubsection{Non-neutral intonation}

In a declarative sentence in which one constituent receives particular emphasis, the non-neutral intonation pattern is used. Instead of being located on the final word, the main pitch accent is located on the focus constituent, which is not restricted to appearing in any particular syntactic position. For example, in (32), the focus 
constituent Roman appears in initial position. It bears the main pitch accent, a falling contour $(\mathrm{H}+\mathrm{L})$, which is followed by a low plateau that extends to a final $\mathrm{L} \beta$ boundary tone. This non-neutral declarative tune $(\mathrm{H}+\mathrm{L} \mathrm{L} \beta)$ contrasts with the neutral declarative tune $(\mathrm{H} \mathrm{L} \beta)$ described and exemplified in Section 5.2.1 in terms of the characteristic pitch accent and its possible location.

(32) ROMAN je=Heleni hvalil Marjano.

Roman.NOM AUX.3SG=Helena.DAT praise.PTCP.SG Marjana.ACC

'ROMAN praised Marjana to Helena.'

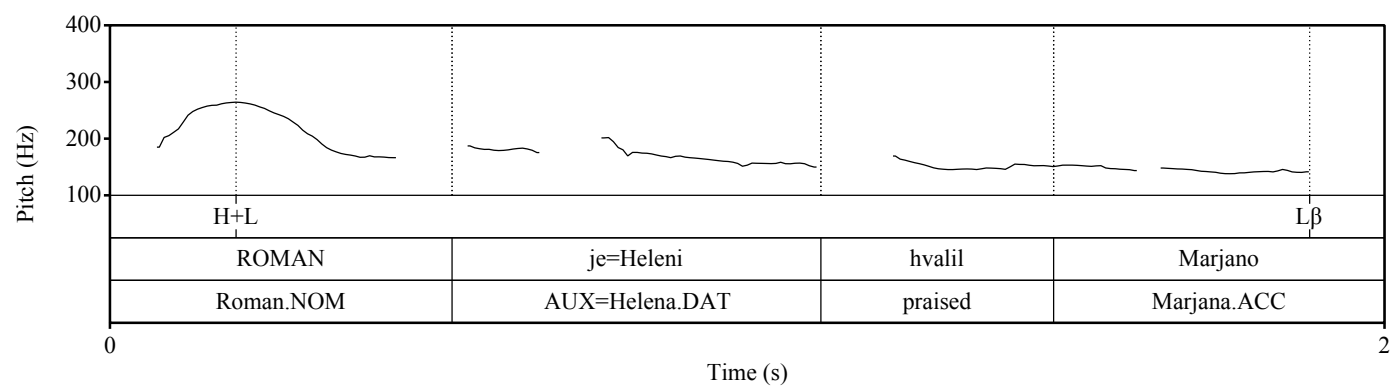

A QWQ does not display the same pattern of intonation as a non-neutral declarative. In fact, it has more in common with neutral declarative intonation. In (33) we see a peak on the sentence-initial question word followed by an overall falling contour. The intonation of non-neutral declaratives and QWQs differs crucially with respect to the shape of the pitch accent involved. In a non-neutral declarative such as (32), the pitch accent is clearly a fall $(\mathrm{H}+\mathrm{L})$. In the case of a QWQ though, the pitch accent is a $\mathrm{H}$ tone on the initial question word. Subsequently, rather than an immediate sharp fall to $\mathrm{L}$ that initiates a low plateau as in the non-neutral declarative (32), there is a gentle slope continuing to the final boundary tone $L \beta(33) .{ }^{15}$ Compare the gently 
falling slope on Roman in the QWQ in (33) to the low plateau on je=Heleni in the nonneutral declarative (32).

(33) $\mathrm{Komu}=\mathrm{je}$

Roman hvalil

Marjano?

who.DAT=AUX.3SG Roman.NOM praise.PTCP.SG Marjana.ACC

'Who did Roman praise Marjana to?'

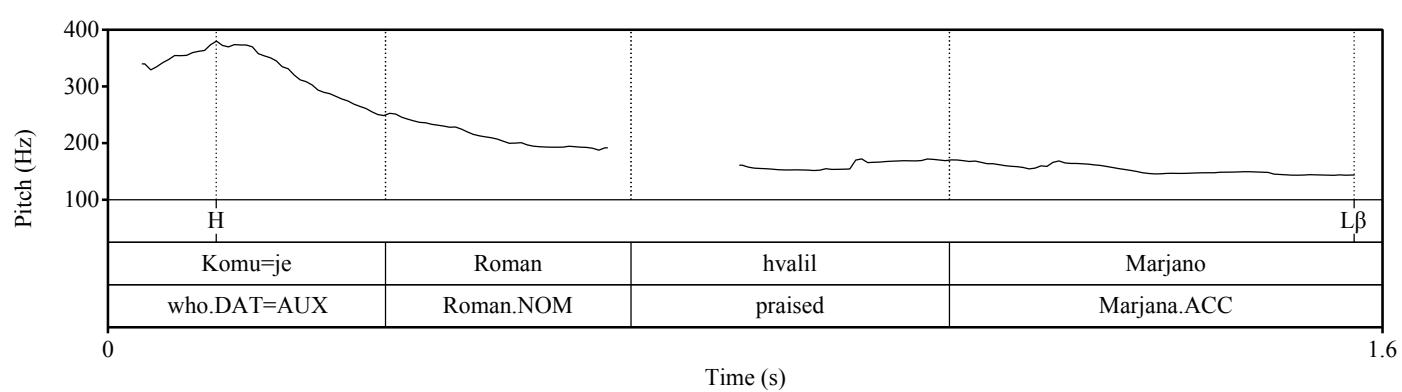

My findings are broadly consistent with previous claims in the literature, apparently based largely on impressionistic accounts of the relevant intonation contours, that a sentence-initial question word bears the main pitch accent (Kř́žzová 1972: 251, cited by Firbas, 1976: 22; Toporišič 1984: 457). The data I have collected also confirm that a falling pattern of intonation is used for both declaratives and QWQs (Toporišič 1984: 456-457), but these data reveal that the falling patterns are not identical. Declaratives end in a short final fall (neutral declarative) or involve a sharp fall followed by a low plateau (non-neutral declarative), whereas in QWQs an initial $\mathrm{H}$ tone is followed by a slow fall to a final low boundary tone. In both QWQs and neutral declaratives the pitch accent involved is a $\mathrm{H}$ tone, which contrasts with non-neutral declaratives where the pitch accent is $\mathrm{H}+\mathrm{L}$. In a QWQ the location of the pitch accent $(\mathrm{H})$ is on the initial question word, while in a neutral declarative the $\mathrm{H}$ pitch accent is located finally. 
When a single-clause interrogative contains multiple question words, the same pattern is used as for other QWQs: the initial question word bears the pitch accent $(\mathrm{H})$ and there is a gentle fall to a final low boundary tone. This pattern is attested regardless of the number of question words or their order. ${ }^{16}$

(34) $\mathrm{Kdo}=\mathrm{je}$

koga Heleni hvalil?

who.NOM=AUX.3SG who.ACC Helena.DAT praise.PTCP.SG

'Who praised who to Helena?'

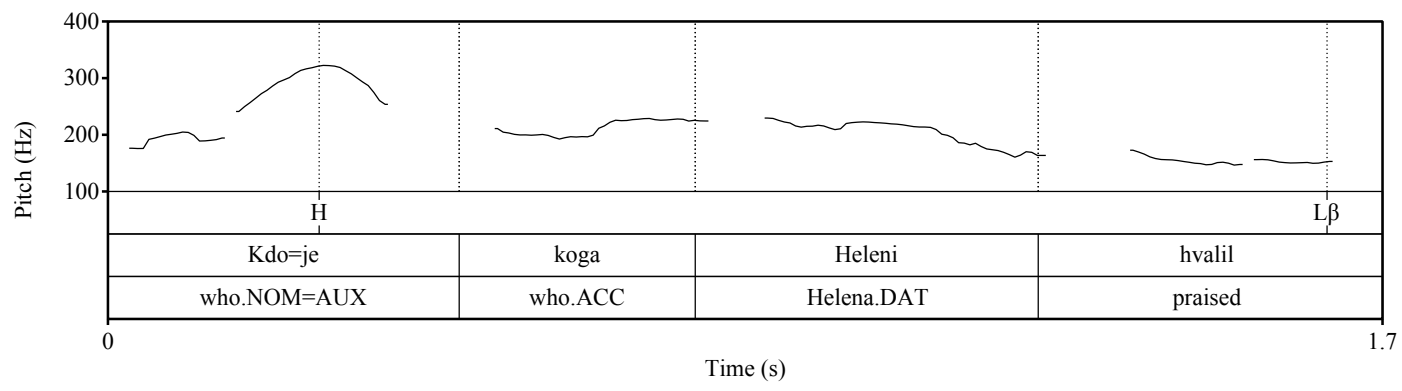

(35) $\mathrm{Kdo}=\mathrm{je}$

koga komu hvalil?

who.NOM=AUX.3SG who.ACC who.DAT praise.PTCP.SG

'Who praised who to who?'

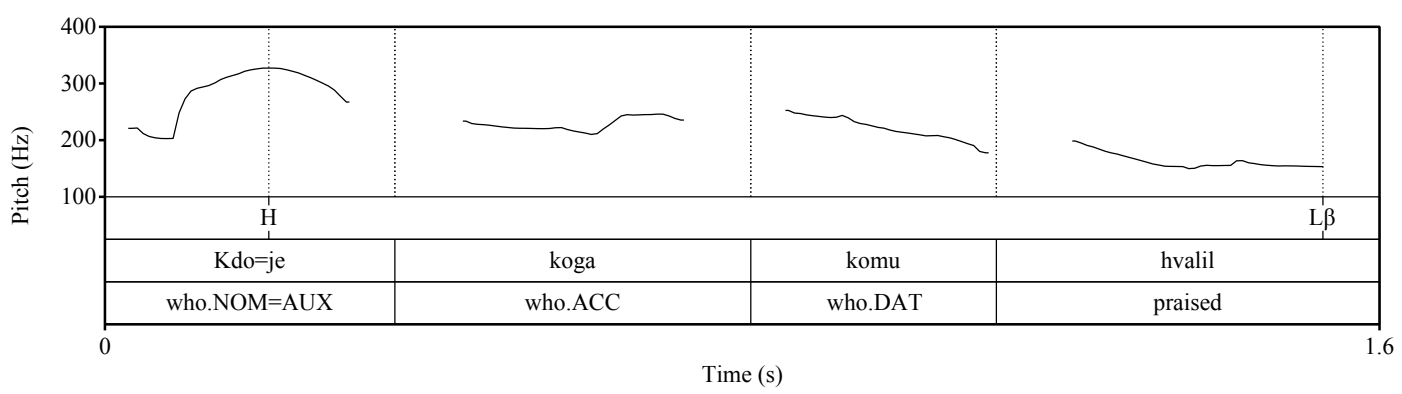

(36) $\mathrm{Kdo}=\mathrm{je} \quad$ komu koga hvalil?

who.NOM=AUX.3SG who.DAT who.ACC praise.PTCP.SG

'Who praised who to who?' 


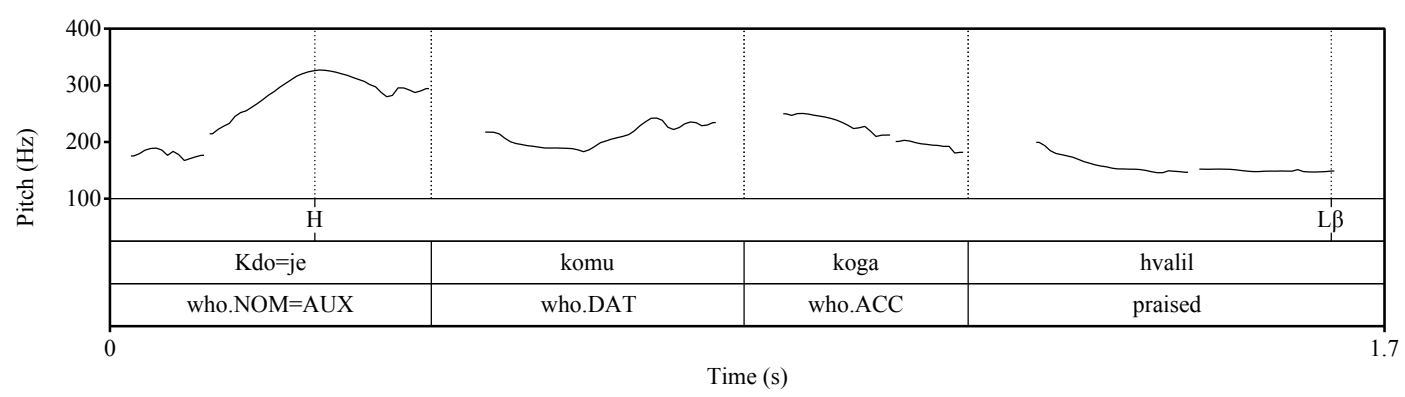

When displacement to a higher clause is involved, the same tune as in examples of single-clause QWQs is observed: $\mathrm{H}$ on the initial question word followed by a falling contour. This fall is not interrupted by the kind of non-final low boundary tones found in multi-clause declaratives; compare (37) with (30) and (31). This is consistent with intonation encoding information about the extent of interrogativity (indicated by underlining), as already observed for multi-clause QWQ matrix questions in Hungarian such as (18).

(37) $\mathrm{Koga}=\mathrm{je}$

Miha

misli $=[\mathrm{da}=\mathrm{je}$

Roman

$\underline{\mathrm{H}}$

who. $\mathrm{ACC}=\mathrm{AUX} \cdot 3 \mathrm{SG}$ Miha.NOM think.PTCP.SG $=$ that $=\mathrm{AUX} \cdot 3 \mathrm{SG}$ Roman.NOM

hvalil

Heleni]?

$\mathrm{L} \beta$

praise.PTCP.SG Helena.DAT

'Who does Miha think Roman praised to Helena? 


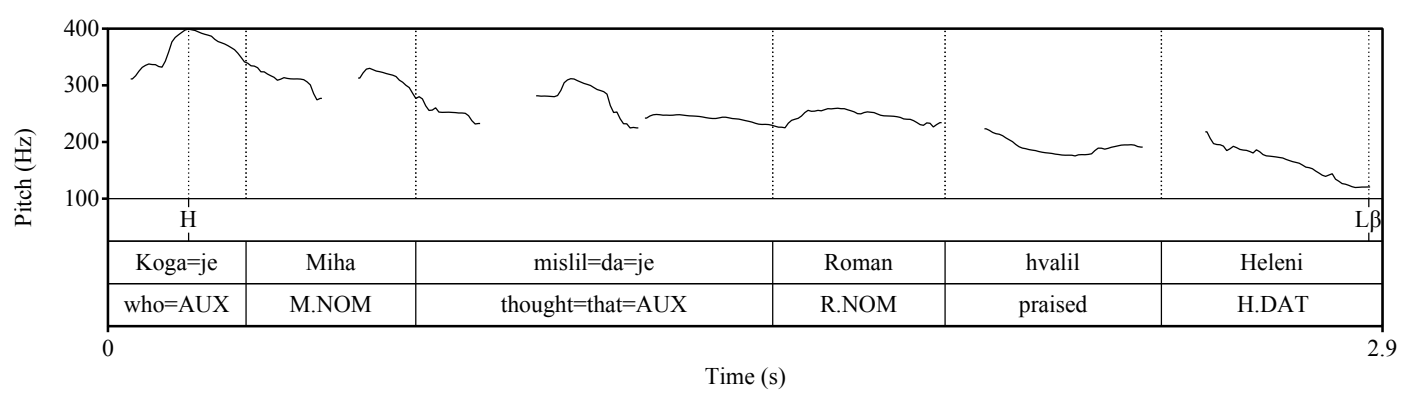

In summary, the intonation contour used with Slovenian QWQs is fundamentally the same as that used with neutral declaratives $(\mathrm{H} \mathrm{L} \beta)$, though the location of the $\mathrm{H}$ pitch accent is different (initial word versus final word). This tune differs from that used with non-neutral declaratives in terms of both the pitch accent $(\mathrm{H}$ versus $\mathrm{H}+\mathrm{L})$ and its location (on the initial word versus on the focus constituent regardless of where it occurs in the sentence). The extent of the QWQ tune coincides with, and thus serves as an indicator of, how much of a sentence is interrogative, i.e. it encodes information about interrogative scope.

\subsection{The Q-marking construction}

As in Section 4.3 on the Q-marking construction in Hungarian, here I present data on the intonation of the Q-marking construction in Slovenian and in light of these consider the three hypotheses in Section 2 concerning pitch accent, tonal contour, and the relationship between the Q-marker and the lower clause containing the associated question word(s).

When only the lower clause containing the associated question phrase is considered, the intonation of the Q-marking construction is directly comparable to that of a QWQ. (38) shows that the associated question word bears the expected H pitch accent and the utterance ends in a $\mathrm{L} \beta$ boundary tone. By contrast in the higher clause, 
the Q-marker bears a different pitch accent, $\mathrm{L}+\mathrm{H}$. The remainder of the Q-marking tune is the same as its QWQ counterpart: in both cases there is a slow fall to a low boundary tone. The two tunes are distinguished in the examples I present by use of single underlining for the QWQ tune and double underlining for the Q-marking tune.

(38) $\mathrm{Kaj}=\mathrm{je}$

$$
\text { Miha mislil, } \quad[\mathrm{komu}=\mathrm{da}=\mathrm{je}
$$

$\underline{\underline{\mathrm{L}}+\mathrm{H}}$ $\mathrm{L} \underline{\beta}$

$\underline{\mathrm{H}}$

QM.ACC=AUX.3SG Miha.NOM think.PTCP.SG who.DAT=that=AUX.3SG

Roman hvalil Marjano]?

$\mathrm{L} \beta$

Roman.NOM praise.PTCP.SG Marjana.ACC

'Who did Miha think Roman praised Marjana to?'

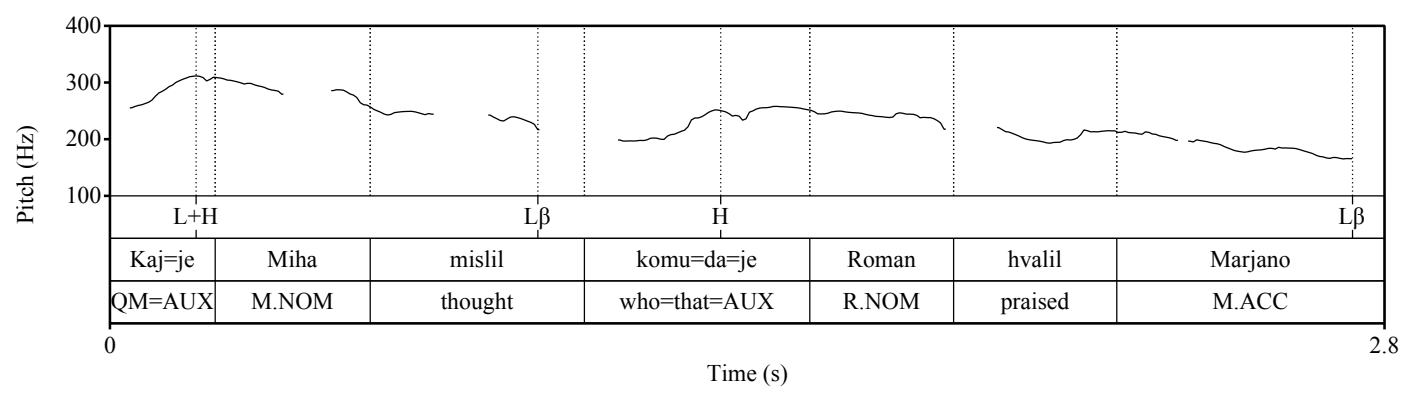

When kaj is a Q-marker, as in (38), it bears a rising $(\mathrm{L}+\mathrm{H})$ pitch accent. However, when kaj is NOT used as a Q-marker, it is associated with a $\mathrm{H}$ tone, just like any other question word in a QWQ, as (39) shows.

(39) $\mathrm{Kaj}=\mathrm{je}$

Roman razlagal?

what. $\mathrm{ACC}=\mathrm{AUX} .3 \mathrm{SG}$ Roman.NOM explain.PTCP.SG

'What did Roman explain?' 


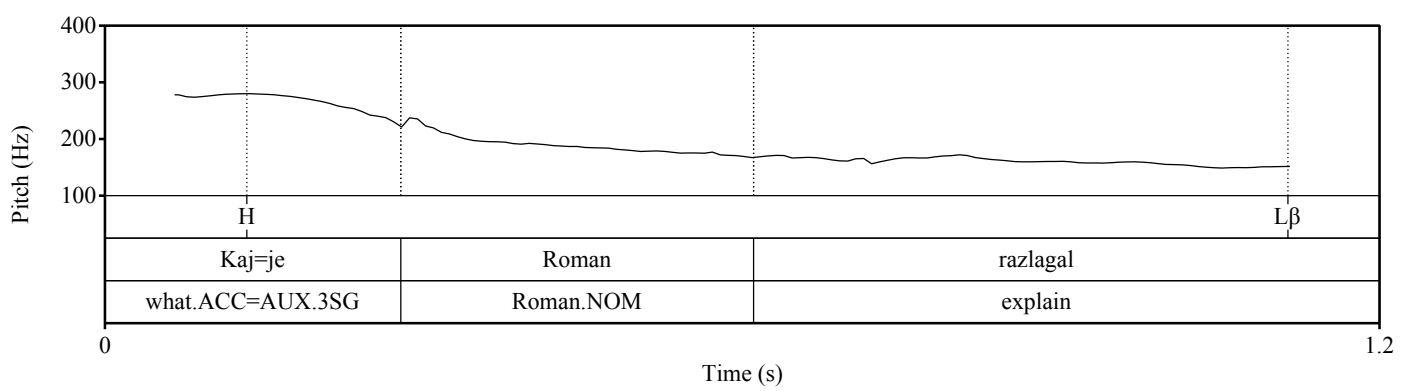

The presence of a low boundary tone at the end of the matrix clause in a Qmarking construction like (40) is apparent when it is compared to a declarative sentence containing an embedded question such as (41). Both of these examples contain the question word koga in clause-initial position in the lower clause, but only in (40) is there evidence that the matrix clause's end coincides with a low boundary tone.

(40) $\mathrm{Kaj}=\mathrm{je}$

Miha mislil,

$[\mathrm{koga}=\mathrm{da}=\mathrm{je}$

$\underline{\underline{\mathrm{L}}+\mathrm{H}}$

$\mathrm{L} \beta$

$\underline{\mathrm{H}}$

QM.ACC $=$ AUX.3SG Miha.NOM think.PTCP.SG who.ACC $=$ that $=$ AUX.3SG

Roman hvalil Heleni]?

Roman.NOM praise.PTCP.SG Helena.DAT

'Who did Miha think Roman praised to Helena?'

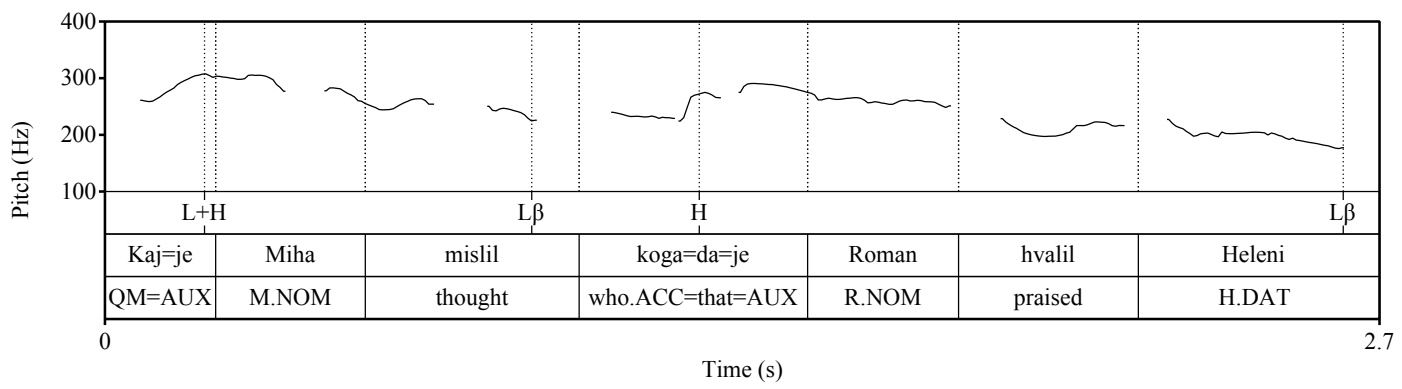


(41) Miha $=\mathrm{je}$

vprašal, $\quad[\mathrm{koga}=\mathrm{je}$

Roman

$\underline{\mathrm{H}}$

Miha.NOM=AUX.3SG ask.PTCP.SG who.ACC=AUX.3SG Roman.NOM

hvalil Heleni].

$\mathrm{L} \beta$

praise.PTCP.SG Helena.DAT

'Miha asked who Roman praised to Helena.'

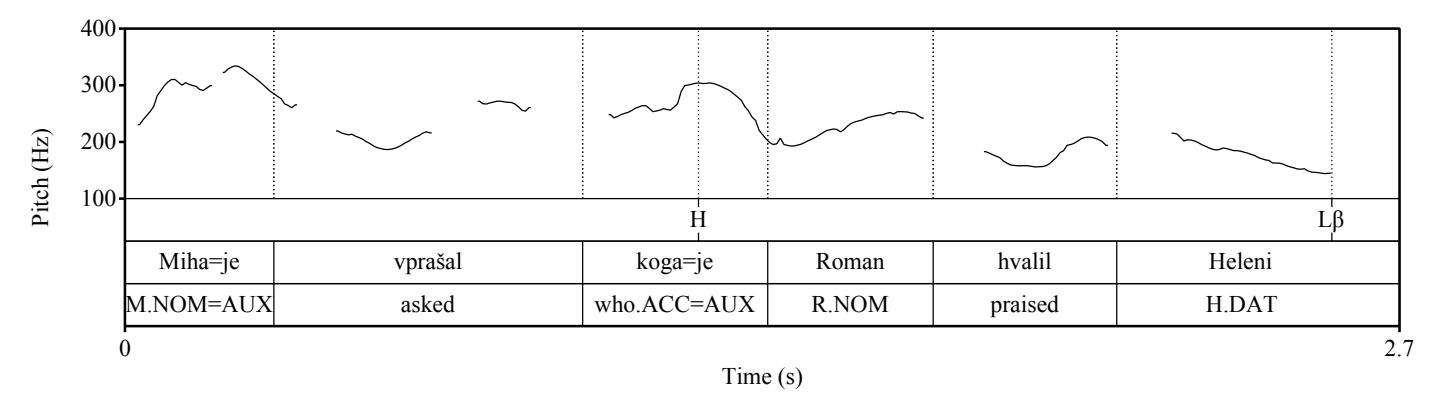

The key features of the Q-marking construction tune in Slovenian are thus: $\mathrm{L}+\mathrm{H}$ $\mathrm{L} \beta \mathrm{H} \mathrm{L} \beta$, with $\mathrm{L}+\mathrm{H}$ being the pitch accent borne by the Q-marker and $\mathrm{H}$ being the pitch accent borne by a question word (specifically, an associated question word in a lower clause) as per the QWQ tune.

When more than one associated question phrase is present in the lower clause, the same intonation pattern is attested. Notice that the $\mathrm{H}$ tone is borne by the first question word $k d o$ (which forms a single prosodic unit with the proceeding clitic cluster comprising $d a=j e)$ in (42); the other question word koga is part of the subsequent slow fall present in other examples. 
(42) $\mathrm{Kaj}=\mathrm{je}$

Miha mislil, $\quad[\mathrm{kdo}=\mathrm{da}=\mathrm{je}$

$\underline{\underline{\mathrm{L}}+\mathrm{H}}$

$\mathrm{L} \underline{\beta}$

$\underline{\mathrm{H}}$

QM.ACC $=$ AUX.3SG Miha.NOM think.PTCP.SG who.NOM=that=AUX.3SG

koga Heleni hvalil]?

$\mathrm{L} \beta$

who.ACC Helena.DAT praise.PTCP.SG

'Who did Miha think praised who to Helena?'

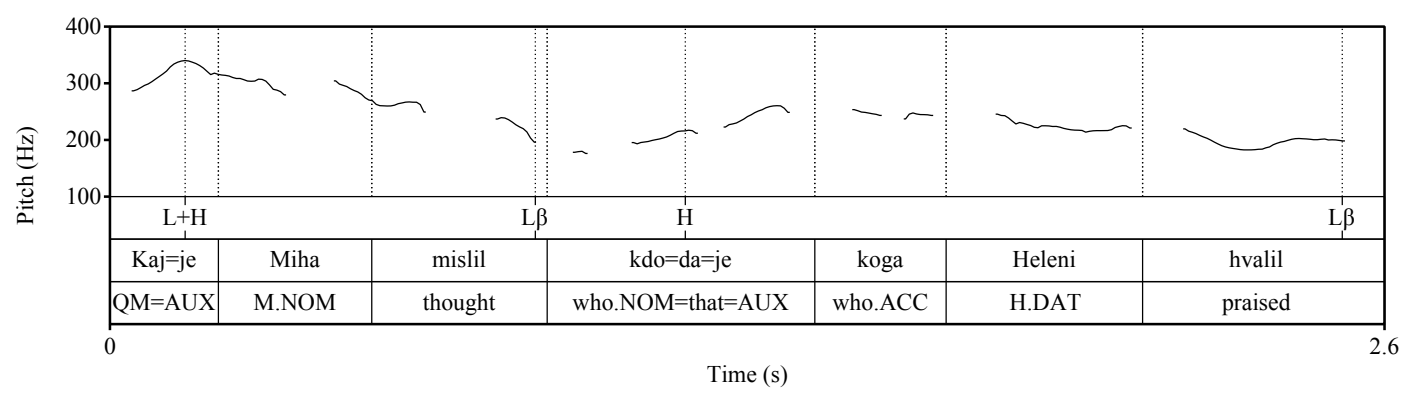

That the intonation pattern associated with Q-marking serves to indicate the extent of interrogative scope is further supported by a variant of the Q-marking construction that is available in Slovenian but not in Hungarian. As stated in Section 2, it is not necessary for a Q-marker to appear in every clause higher than the one containing the associated question phrase in Slovenian. In (43), the slow fall following the $\mathrm{L}+\mathrm{H}$ accent on the Q-marker is even more obvious as it spreads over the matrix clause and the first of the two subordinate clauses, stopping only when the associated question phrase (koga plus enclitic cluster $d a=j e$ ) is reached at the start of the most deeply embedded clause. 
(43) $\mathrm{Kaj}=\mathrm{je}$

Miha $\quad$ mislil $=[\mathrm{da}=\mathrm{je}$

Manuela

$\underline{\underline{\mathrm{L}}+\mathrm{H}}$

QM.ACC=AUX.3SG Miha.NOM think.PTCP.SG=that=AUX.3SG Manuela.NOM

rekla, $\quad[\mathrm{koga}=\mathrm{da}=\mathrm{je} \quad$ Roman hvalil

$\underline{L} \quad \underline{H}$

say.PTCP.SG who.ACC=that $=$ AUX.3SG Roman.NOM praise.PTCP.SG

$\underline{\text { Heleni]]? }}$

$\mathrm{L} \beta$

Helena.DAT

'Who did Miha think that Manuela said that Roman praised to Helena?'

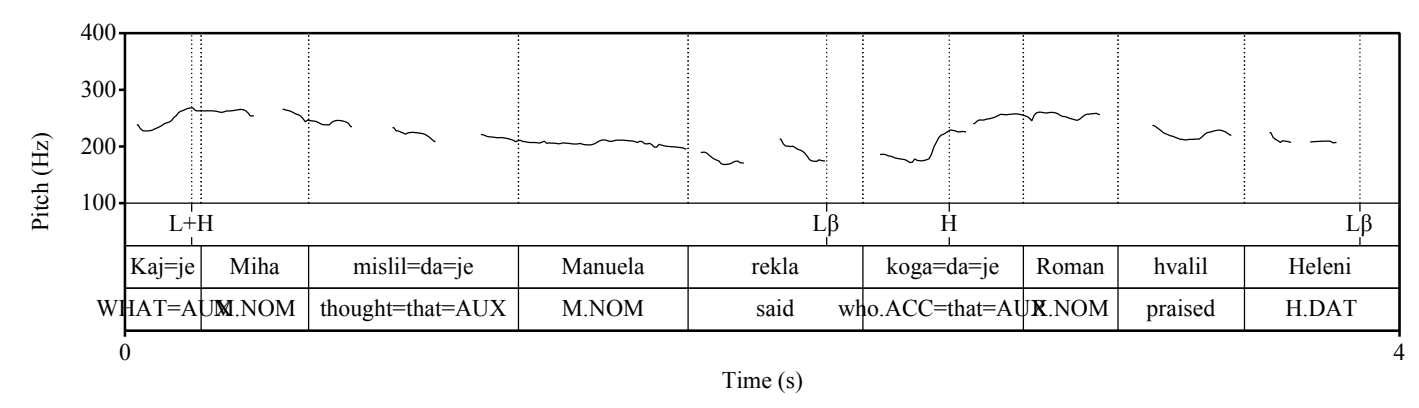

The example in (43) demonstrates that the $\mathrm{L}+\mathrm{H} \mathrm{L} \beta$ pattern extends not simply to the first clause boundary it reaches, but to the first clause boundary it reaches that is immediately followed by a clause-initial associated question phrase. This is consistent with an intonational indication of the extent of interrogative scope, comparable to QWQs in both Slovenian (37) and Hungarian (18), and in the Q-marking construction in Hungarian (23). The requirement for the domain of these tunes to coincide in some way with the extent of interrogative scope overrides any requirement for boundary tones and clause boundaries to align, regardless of whether the tune concerned is initiated by a Q- 
marker or a question phrase; compare the syntactic units (indicated by square brackets) and the intonational units (indicated by underlining) in (18), (23), (37) and (43).

Table 2 summarizes the characteristics of Slovenian intonation as analysed in this section and Section 5.2.

\begin{tabular}{|c|c|c|}
\hline \multicolumn{2}{|c|}{ Sentence type } & Tune \\
\hline \multicolumn{2}{|c|}{ Neutral declarative } & H L $\beta$ \\
\hline \multirow{3}{*}{ Non-neutral } & - declarative & $\mathrm{H}+\mathrm{L} \mathrm{L} \beta$ \\
\hline & $\begin{array}{ll}\text { QWQ } \\
\text { (pitch accent on initial question word) }\end{array}$ & $\mathrm{H} \mathrm{L} \beta$ \\
\hline & $\begin{array}{l}\text { Q-marking construction } \\
\text { (first pitch accent on a Q-marker, final pitch accent on the } \\
\text { initial associated question word) }\end{array}$ & $\mathrm{L}+\mathrm{H} \mathrm{L} \beta \mathrm{H} \mathrm{L} \beta$ \\
\hline
\end{tabular}

Table 2

Characteristic intonation patterns of declaratives, QWQs, and the Q-marking construction in Slovenian

With respect to the three hypotheses stated at the end of Section 2 (each summarized below for ease of reference), the following conclusions can be drawn about the Q-marking construction in Slovenian.

H1: Q-markers and question words bear the same pitch accent (consistent with the indirect dependency analysis).

CONCLUSION: Q-markers do not bear the same pitch accent as question words.

A Q-marker bears a $\mathrm{L}+\mathrm{H}$ pitch accent, while a question word bears a $\mathrm{H}$ pitch accent. The two are therefore distinct, which challenges the view that a Q-marker is a question word like any other. If the Q-marker were a question word quantifying over propositions as proposed, it would be 'the standard wh-word for clausal complements' as used in QWQs such as What do you think? (Fanselow 2006: 451), which in Slovenian would be the word for 'what'. However, comparison of this use of 'what', as in (44), with examples of the Q-marking construction shows that kaj bears a different 
pitch accent depending on whether it functions as the 'wh-word for clausal complements' (the usual H used with a question word, as in 44) or the Q-marker $(\mathrm{L}+\mathrm{H}$, as in 43).

$(44)$
Miha
mislil?
what.ACC $=$ AUX.3SG Miha.NOM think.PTCP.SG

'What did Miha think?'

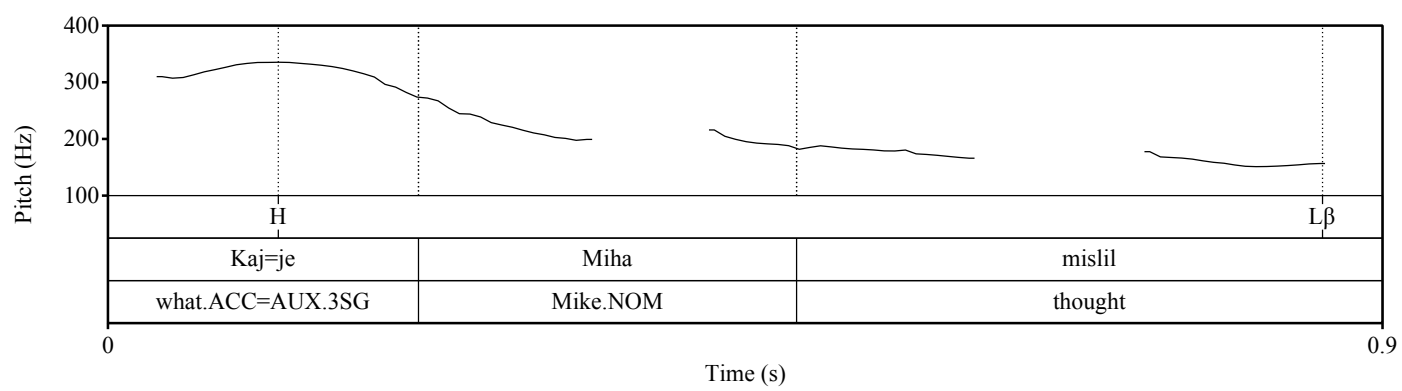

Such data undermine the claim that the two instances of 'what' are the same and therefore that the Q-marker is a question word.

H2: The lower clause in a Q-marking construction has exactly the same intonational properties as a QWQ.

CONCLUSION: The intonational characteristics of the lower clause in a Q-marking construction are the same as those of other QWQs.

A QWQ's characteristic tune comprises an initial H pitch accent, followed by a low plateau and ending with a low boundary tone. In the clause containing the associated question phrase(s) in a Q-marking construction, the same tune is identifiable. Moreover, the lower clause in a Q-marking construction in Slovenian also shares an important syntactic feature with a QWQ: both begin with a question phrase. This is because the complementizer $d a$ 'that' is a P2 clitic. It therefore appears AFTER the initial 
question word in any subordinate clause. The result is that the first associated question phrase in a Q-marking construction simultaneously represents the beginning of a lower clause in the Slovenian Q-marking construction. This alignment has a bearing on the testing of hypothesis H3.

H3: The Q-marking construction's intonation is consistent only with a relationship existing between a Q-marker and the entire lower clause containing the associated question phrase(s) (indirect dependency analysis) and NOT between a Q-marker and the associated question phrase(s) in a lower clause (direct dependency analysis).

CONCLUSION: The Q-marking construction's intonation is consistent with both possibilities; that is, with a relationship existing between a Q-marker and the associated question phrase(s) in a lower clause (direct dependency analysis) or between a Qmarker and the entire lower clause containing the associated question phrase(s) (indirect dependency analysis).

In a Q-marking construction, a Q-marker bears a rising $(\mathrm{L}+\mathrm{H})$ pitch accent, which is followed by a slow fall to a low boundary tone before the characteristic QWQ tune is initiated by an associated question phrase in the lower clause ( $\mathrm{H}$ on the question word at the start of the clause, then a slow fall to a final boundary tone L $\beta$ ). The associated question word in a lower clause that bears the $\mathrm{H}$ pitch accent occupies clause-initial position, so it simultaneously marks the start of the QWQ tune and the start of the lower clause including the associated question phrase(s). This makes it impossible to tease apart whether the intonational link observed is between the Q-marker and associated question phrase at the start of the lower clause (direct dependency) or between the Qmarker and the entire lower clause whose left edge that initial associated question 
phrase represents (indirect dependency). This means that the Slovenian Q-marking construction's intonation is compatible with both the direct and indirect dependency analyses of its structure.

\section{COMPARING THE INTONATION OF Q-MARKING CONSTRUCTIONS}

The data analysed in Sections 4 and 5 enable the intonation of Q-marking constructions in different languages to be compared for the first time. Table 3 summarizes the findings of this study in relation to the main pitch accent borne by a question word in a QWQ, an associated question phrase in a Q-marking construction, and a Q-marker in a Q-marking construction in each of the case-study languages.

\begin{tabular}{lll}
\hline & Hungarian & Slovenian \\
\hline Question word in a QWQ & $\mathrm{H}+\mathrm{L}$ & $\mathrm{H}$ \\
\hline Associated question word in a Q-marking construction & $\mathrm{H}+\mathrm{L}$ & $\mathrm{H}$ \\
\hline Q-marker in a Q-marking construction & $\mathrm{H}+\mathrm{L}$ & $\mathrm{L}+\mathrm{H}$ \\
\hline
\end{tabular}

Table 3

Main pitch accent borne by a question word in a QWQ, an associated question word and a Q-marker in Hungarian and Slovenian

Table 4 lists the tunes used with questions in the case-study languages. In both cases, the first pitch accent in the Q-marking tune is borne by a Q-marker, while the final pitch accent is borne by an associated question phrase; see also Table 3 . The intonation pattern associated with the lower clause in a Q-marking construction either shares most of its properties with (Hungarian) or is identical to (Slovenian) the QWQ tune in that language.

\begin{tabular}{lll}
\hline Sentence type & Tune in Hungarian & $\begin{array}{l}\text { Tune in } \\
\text { Slovenian }\end{array}$ \\
\hline QWQ & $(\beta \mathrm{H}) \mathrm{H}+\mathrm{L} \mathrm{L} \beta$ & $\mathrm{H} \mathrm{L} \beta$ \\
\hline Q-marking construction & $\mathrm{H}+\mathrm{L} \mathrm{L} \beta \mathrm{H}+\mathrm{L} \mathrm{L} \beta$ & $\mathrm{L}+\mathrm{H} \mathrm{L} \beta \mathrm{H} \mathrm{L} \beta$ \\
\hline
\end{tabular}


Characteristic intonation patterns of QWQs and the Q-marking construction in Hungarian and Slovenian

Table 5 summarizes my findings in relation to the three hypotheses set out in Section 2.

\begin{tabular}{lll}
\hline Hypothesis & Hungarian & Slovenian \\
\hline $\begin{array}{l}\text { H1: Q-markers and question words bear same } \\
\text { pitch accent } \\
\text { (consistent with indirect analysis) }\end{array}$ & Yes & No \\
\hline $\begin{array}{l}\text { H2: Lower clause in a Q-marking construction } \\
\text { has exactly }\end{array}$ & $\begin{array}{l}\text { No, but they share many } \\
\text { features }\end{array}$ & Yes \\
$\begin{array}{lll}\text { H3: Intonation is consistent only with an } \\
\begin{array}{l}\text { indirect relationship } \\
\text { between Q-markers and associated question } \\
\text { phrases }\end{array}\end{array}$ & No No \\
\hline
\end{tabular}

Table 5

Results of testing hypotheses H1-H3 (Section 2)

The similarities and differences identified have implications for proposed analyses of the Q-marking construction. Recall that according to an indirect dependency analysis, the Q-marker is a question word like any other, and that it is related to the entire lower clause containing the associated question phrase(s). Under a direct dependency analysis, by contrast, the Q-marker is an expletive element inserted only to extend the scope of the associated question phrase(s), with which the Q-marker has a direct relationship.

In Slovenian the Q-marker bears a pitch accent that distinguishes it from question words, including the homophonous question word used for clausal complements (Section 5.3). This is not consistent with an indirect dependency analysis but is in line with the direct dependency analysis. In Hungarian, the Q-marker bears the same pitch accent as other question words. However, this pitch accent is a defining characteristic of 
non-neutral intonation more generally in Hungarian: it is borne by a variety of scopetaking elements ('operators') which appear in non-neutral sentences, including Focus constituents that are not question words (Section 4.2.2). Thus the Hungarian data are also compatible with an analysis of the Q-marker as being a Focus expletive, as per the direct dependency analysis. When intonation in both languages is considered, the data do not support a unified, cross-linguistic indirect dependency analysis according to which a Q-marker is a question word.

It is clear that the intonation of the lower clause containing the associated question phrase(s) is in fundamental respects the same as that of a QWQ in the languages under consideration. In all cases, an associated question word bears the usual pitch accent characteristic of the QWQ tune, and this is followed by the usual slow fall (Slovenian) or low plateau (Hungarian) to a final low boundary tone. In a QWQ, the extent of this tune is an indicator of the extent of interrogativity (i.e. how much of the sentence is a question), stretching from a question phrase to the end of the sentence. In an embedded question, the QWQ tune starts in an embedded clause. In a matrix question, the QWQ tune starts in the matrix clause and stretches over the embedded clause. In both cases, the QWQ tune terminates only at the end of the sentence. Such intonational encoding of interrogative scope is also a feature of the Q-marking construction, but the intonation pattern characteristic of a Q-marking construction comprises a number of sequential contours, each associated with a scope-taking element, that together indicate the full extent of the interrogativity involved.

The Q-marking construction involves extension of interrogative scope as marked by the presence of a Q-marker in a higher clause (Section 2), i.e. extension of scope encoded in the syntax. The data presented in this paper have shown for the first time 
that this extension of scope is concomitantly encoded in the distinctive tune initiated by a Q-marker in Hungarian and Slovenian. As data including the Slovenian Q-marking construction in (43) illustrate, the component parts of the Q-marking tune are not restricted by clause boundaries. The relevant contours may traverse syntactic boundaries, continuing until another scope-taking element (which bears a pitch accent) is reached. The Q-marking tune thus comprises identifiable consecutive instances of intonational scope marking, which together also represent an example of intonational scope marking, one that marks the extension of interrogative scope.

When it comes to determining whether the relationship between a Q-marker and associated question phrase is direct or indirect, the Slovenian intonation data are ambiguous. In Slovenian the associated question word that bears a pitch accent is clause initial, meaning that the sequential contours that characterize the Q-marking tune each align with the beginning of a clause. The relationship involved can therefore be characterized as being either between the Q-marker and the associated question phrase(s) (direct dependency) or between the Q-marker and the entire lower clause that begins with the associated question phrase(s) (indirect dependency). The two possibilities cannot be teased apart. By contrast, in Hungarian the intonational link between a Q-marker and the final/only associated question phrase appears to be direct because the low plateau following the pitch accent on the Q-marker can extend across a clause boundary into a lower clause, up to the associated question phrase in immediately preverbal position that bears a pitch accent and initiates another QWQ-type tune; see, for instance (21), (23), (24). The intonational 'chain' that is formed in a Hungarian Q-marking construction links scope-marking elements - Q-markers and 
associated question phrases - to one another, consistent with there being a direct dependency between them.

\section{CONCLUSION}

In this paper, I have shown that intonational encoding of interrogative scope is a feature of QWQs and the Q-marking construction in Hungarian and Slovenian. The Q-marking construction is associated with a tune comprising successive contours (pitch accent plus low boundary tone), each of which serves to indicate the scope of the element (Qmarker or associated question phrase) that bears the pitch accent. These distinct, consecutive indicators of interrogative scope together form an intonational 'chain' that indicates the full extent of interrogativity involved in a Q-marking construction.

This investigation of the Q-marking construction and its intonation in Hungarian and Slovenian has revealed hitherto unidentified aspects of variation. In Slovenian, the Q-marker bears a pitch accent that distinguishes it from question words; this is not the case in Hungarian. While data from both languages show that the extent of interrogative scope is marked intonationally, the non-clause-initial position of Q-markers and question phrases in Hungarian indicates that an intonational link exists between a Qmarker and the final/only associated question word, consistent with a direct relationship existing between the two. The intonation data considered in this paper thus do no support a unified, cross-linguistic indirect dependency analysis of the Q-marking construction.

In this first comparative study of the intonation of the Q-marking construction, I chose as case studies two unrelated multiple-fronting languages. Looking ahead, it will be important to compare the findings reported here with data on the intonation of the Q- 
marking construction in simple-fronting languages such as German, as well as 'bare' scope marking in languages such as Malay. Bare scope marking is of particular interest given that in this type of construction there is no Q-marker in a higher clause to indicate that the scope of a question phrase has been extended (hence the scope marking is 'bare'). The possibility arises in relation to bare scope marking that, rather than syntax and intonation simultaneously encoding information about interrogative scope extension, intonation may play a critical role. Such research is likely to represent a significant challenge given that, similar to the present study, it may require the elicitation and analysis of spoken data from languages whose intonational patterns have not yet been fully documented and/or verified by instrumental studies. However, the insights reported in this paper - not only into the intonation of the Q-marking construction but also in relation to scope-marking, and what these reveal about interaction between syntax, prosody, and semantics - show that such research has the potential to provide new perspectives on the structure of questions cross-linguistically. 


\section{REFERENCES}

Bennett, David C. 1986. Towards an explanation of word-order differences between Slovene and Serbo-Croat. The Slavonic and East European Review 64, 1-24.

Boersma, Paul \& David Weenink. 2018. Praat: doing phonetics by computer [Computer program], version 6.0.40. http://www.praat.org/ (retrieved 11 May 2018).

Cheng, Lisa Lai-Shen. 1997. On the typology of wh-questions. London: Garland Publishing, Inc.

Chomsky, Noam. 1977. On wh-movement. In Peter W. Culicover, Thomas Wasow \& Adrian Akmajian (eds.), Formal syntax, 71-132. London: Academic Press, Inc.

Cole, Peter \& Gabriella Hermon. 1998. The typology of wh-movement: wh-questions in Malay. Syntax 1, 221-258.

Cole, Peter \& Gabriella Hermon. 2000. Partial wh-movement: Evidence from Malay. In Lutz et al. (eds.), 101-130.

Dayal, Veneeta. 1994. Scope marking as indirect wh-dependency. Natural Language Semantics 2, 137-170.

Dayal, Veneeta. 2000. Scope-marking: Cross-linguistic variation in indirect dependency. In Lutz et al. (eds.), 157-193.

É. Kiss, Katalin. 2002. The syntax of Hungarian. Cambridge: Cambridge University Press.

Fanselow, Gisbert. 2006. Partial wh-movement. In Martin Everaert \& Henk van Riemsdijk (eds.), The Blackwell companion to syntax, vol. III, 437-492. Oxford: Blackwell.

Felser, Claudia. 2001. Wh-expletives and secondary predication: German partial whmovement reconsidered. Journal of Germanic Linguistics 13, 5-38. 
Firbas, Jan. 1976. A study in the functional perspective of the English and the Slavonic interrogative sentence. Brno Studies in English 12, 9-56.

Franks, Steven \& Tracy Holloway King. 2000. A handbook of Slavic clitics. Oxford: Oxford University Press.

Genzel, Susanne, Shinichiro Ishihara \& Balázs Surányi. 2015. The prosodic expression of focus, contrast and givenness: A production study of Hungarian. Lingua 165, 183204.

Golden, Marija. 1996. Interrogative wh-movement in Slovene and English. Acta Analytica 14, 145-186.

Greenberg, Marc L. 2003. Word prosody in Slovene from a typological perspective. Sprachtypologie und Universalienforschung 56, 234-251.

Gussenhoven, Carlos. 2004. The phonology of tone and intonation. Cambridge: Cambridge University Press.

Gvozdanović, Jadranka 1999. South Slavic prosody. In Harry van der Hulst (ed.), Word prosodic systems in the languages of Europe, 839-852. Berlin: Mouton de Gruyter.

Gyuris, Beáta \& Katalin Mády. 2013. Approaching the prosody of Hungarian whexclamatives. In Péter Szigetvari (ed.), VLLXX: Papers presented to László Varga on his 70th birthday. http://seas3.elte.hu/VLlxx/gyuris-mady.html (accessed 22 June 2016).

Hayes, Bruce \& Aditi Lahiri. 1991. Bengali intonational phonology. Natural Language \& Linguistic Theory 9, 47-96.

Horvath, Julia. 1997. The status of ' $w h$-expletives' and the partial $w h$-movement construction of Hungarian. Natural Language \& Linguistic Theory 15, 509-572. 
Hunyadi, László. 2002. Hungarian sentence prosody and Universal Grammar: On the prosody-syntax interface. New York: Peter Lang.

Jun, Sun-Ah (ed.). 2005. Prosodic typology: The phonology of tone and intonation. Oxford: Oxford University Press.

Jun, Sun-Ah (ed.). 2014. Prosodic typology II: The phonology of intonation and phrasing. Oxford: Oxford University Press.

Jurgec, Peter. 2007. Schwa in Slovenian is epenthetic. Presented at the 2nd Congress of the Slavic Linguistics Society, Berlin. www.hum.uit.no/a/jurgec/schwa.pdf (accessed 14 December 2011).

Kálmán, László. 1985a. Word order in neutral sentences. In István Kenesei (ed.), Approaches to Hungarian, vol. 1: Data and descriptions, 13-23. Szeged: JATE.

Kálmán, László. 1985b. Word order in non-neutral sentences. In István Kenesei (ed.), Approaches to Hungarian, vol. 1: Data and descriptions, 25-37. Szeged: JATE.

Kálmán, László, Gabor Prószéky, Ádám Nádasdy, \& C. György Kálmán. 1986. Hocus, focus, and verb types in Hungarian infinitive constructions. In Werner Abraham \& Sjaak de Meij (eds.), Topic, focus and configurationality: Papers from the $6^{\text {th }}$ Groningen Grammar Talks, Groningen, 1984, 129-142. Amsterdam: John Benjamins.

Kenesei, István. 1998a. Adjuncts and arguments in VP-focus in Hungarian. Acta Linguistica Hungarica 45, 61-88.

Kenesei, István. 1998b. On the syntactic options of focus. Ms., University of Szeged. Křížková, Helena. 1972. Kontextové členění a typy tázacích vět v současných slovanských jazycích [Contextual organisation (functional sentence perspective) and 
types of interrogative sentence in contemporary Slavonic languages]. Slavia 41, 241262.

Laczkó, Tibor. 2014. An LFG analysis of verbal modifiers in Hungarian. In Miriam Butt \& Tracy Holloway King (eds.), Proceedings of the LFG 2014 Conference. Online: CSLI Publications. http://csli-publications.stanford.edu/ (accessed 22 June 2016).

Ladd, D. Robert. 2008. Intonational phonology, 2nd edn. Cambridge: Cambridge University Press.

Lecarme, Jacqueline. 1999. Focus in Somali. In Georges Rebuschi \& Laurice Tuller (eds.), The grammar of focus, 275-309. Amsterdam: John Benjamins.

Lipták, Anikó. 2001. On the syntax of wh-items in Hungarian. Utrecht: LOT.

Lutz, Uli, Gereon Müller \& Arnim von Stechow (eds.). 2000. Wh-scope marking. Amsterdam: John Benjamins.

McDaniel, Dana. 1989. Partial and multiple wh-movement. Natural Language \& Linguistic Theory 7, 565-604.

Mády, Katalin. 2015. Prosodic (non-)realisation of broad, narrow and contrastive focus in Hungarian: A production and a perception study. Interspeech 15 (Proceedings of the 16th Annual Conference of the International Speech Communication Association Interspeech), 948-952.

Mády, Katalin \& Ádám Szalontai. 2014. Where do questions begin? - phrase-initial boundary tones in Hungarian polar questions. 7th International Conference on Speech Prosody (SP 2014), Dublin. http://real.mtak.hu/20307/1/MadySzalontaiPolarquestionsInitialtones_2014.pdf (accessed 22 June 2016). 
Mahajan, Anoop. 2000. Towards a unified treatment of wh-expletives in Hindi and German. In Lutz et al. (eds.), 317-332.

Marušič, Franc. 2008. CP under control. In Gerhild Zybatow, Luka Szucsich, Uwe Junghanns \& Roland Meyer (eds.), Formal description of Slavic languages, 408422. Frankfurt am Main: Peter Lang.

Marušič, Franc. 2007. On the lack of a (PF) phase in non-finite clausal complements. Proceedings of ConSOLE XIV, 203-225.

Marušič, Franc \& Rok Žaucer. 2006. Review article on Janez Orešnik \& Donald F. Reindl (eds.), Slovenian from a typological perspective, 2003. Journal of Slavic Linguistics 14, 123-160.

Mycock, Louise. 2006. The typology of constituent questions: A Lexical-Functional Grammar analysis of 'wh'-questions. Ph.D. thesis, University of Manchester.

Mycock, Louise. 2010a. Prominence in Hungarian: Alignment and the syntax-prosody interface. In Louise Mycock \& Nigel Vincent (eds.), The prosody-syntax connection, thematic issue of Transactions of the Philological Society 108, 265-297.

Mycock, Louise. 2010b. Multiple-clause constituent questions: Intonation and variation in Hungarian. Acta Linguistica Hungarica 57, 268-287.

Pierrehumbert, Janet B. 1980. The phonetics and phonology of English intonation. Ph.D. thesis, MIT.

Pierrehumbert, Janet B. \& Mary E. Beckman. 1988. Japanese tone structure. Cambridge, MA: MIT Press.

Puskás, Genoveva. 2000. Word order in Hungarian: The syntax of Ā-positions. Amsterdam: John Benjamins. 
Riemsdijk, Henk van. 1983. The Correspondence Effect and the Empty Category Principle. In Yukio Otsu, Henk van Riemsdijk, Kazuko Inoue, Akio Kamio \& Noriko Kawasaki (eds.), Studies in Generative Grammar and language acquisition: A report on recent trends in linguistics, 5-16. Tokyo: Tokyo Gakugei University.

Rosenthall, Sam. 1992. The intonation of simple sentences in Hungarian. Papers from the 3rd Annual Formal Linguistics Society of Midamerica, 297-310.

Rudin, Catherine. 1988. On multiple questions and multiple fronting. Natural Language \& Linguistic Theory 6, 445-501.

Saddy, Douglas. 1991. WH scope mechanisms in Bahasa Indonesia. MIT Working Papers in Linguistics 15, 183-218.

Staudacher, Peter. 2000. Partial movement and compositionality. In Josef Bayer \& Christine Römer (eds.), Von der Philologie zur Grammatiktheorie Peter Suchsland zum 65. Geburtstag, 191-211. Tübingen: Max Niemeyer Verlag.

Šuštaršič, Rastislav. 2005. English-Slovene contrastive phonetic and phonemic analysis and its application in teaching English phonetics and phonology. Ljubljana: Znanstveni inštitut Filozofske fakultete.

Šuštaršič, Rastislav \& Hotimir Tivadar. 2005. Perception of tonemicity in Standard Slovene. Govor 22: 23-35.

Szabolcsi, Anna. 1997. Strategies for scope taking. In Anna Szabolcsi (ed.), Ways of scope taking, 109-154. Dordrecht: Kluwer.

Szendröi, Kriszta. 2001. Focus and the syntax-phonology interface. Ph.D. thesis, University College London.

Toporišič, Jože. 1984. Slovenska slovnica [Slovene grammar], 2nd edn. Maribor: Založba Obzorja. 
Varga, László. 2002. Intonation and stress: Evidence from Hungarian, Basingstoke:

Palgrave Macmillan.

Woznicki, Katherine. 2006. An acoustic analysis of word prosody in Ljubljana Slovene. Senior Honors thesis, Ohio State University. 


\section{FOOTNOTES}

${ }^{1}$ I would like to thank Rick Gartner, Mária Gósy, Tekla Etelka Gráczi, Darja

Hoenigman, Kerstin Hoge, Viktória Horváth, Matjaž Justin, Aditi Lahiri, Albina Nećak Lük, Maruška Markovčič, Alexandra Markó, Attila Mártonfi, Lenka Meszler, Helena Seražin, Rastislav Šuštaršič, Tamás Péter Szabó, Nigel Vincent, Damjana Žbontar, and Maja Zupančič Justin for their time and assistance, and to three anonymous Journal of Linguistics reviewers for their invaluable insights. This work was supported by a British Academy Postdoctoral Fellowship and a Postdoctoral Studies Research Scholarship awarded by the Hungarian Scholarship Board (Magyar Ösztöndíj Bizottság).

In this paper, the Leipzig Glossing conventions are augmented with the following: INE inessive, QM Q-marker, and VM verbal modifier.

${ }^{2}$ I use the term Q-marking construction in order to remain as theory neutral as possible. This construction has also been referred to in the literature as partial 'wh'-movement, 'wh'-scope marking, and the 'wh'-expletive construction (e.g. Cole \& Hermon 2000, Lutz et al 2000, Mahajan 2000, respectively).

${ }^{3}$ On 'bare' scope marking, see Cole \& Hermon (1998, 2000), Mycock (2006), Saddy (1991), inter alia.

${ }^{4}$ For more on the properties of scope marking constructions, see Fanselow (2006).

${ }^{5}$ Verb forms differ in these sentences because two conjugations exist in Hungarian whose usage depends on whether a definite object is present, as in (11a-b), or not, as in (11c).

${ }^{6}$ This is not the only way that a multiple QWQ can be formed in Hungarian. On other possibilities and the differences between them, see Lipták (2001). 
${ }^{7}$ Whether the low plateau that results is due to the eradication of stress or pitch range compression has yet to be determined conclusively; on this see, for example, Kálmán et al (1986), Kenesei (1998a).

${ }^{8}$ Intonation contours are abstract tunes. There is no expectation that the value of, for instance, every $\mathrm{H}$ tone will be equivalent in terms of its value in $\mathrm{Hz}$.

${ }^{9}$ The fact that both Q-markers and question phrases behave like other operators in initiating an intonation contour that coincides in the usual way with their scope brings to mind Szabolcsi's (1997: 111) description of Hungarian as being 'a language that "wears its [Logical Form] on its sleeve"'. Based on the data presented here, that statement holds true with respect not only to its syntactic structure but also to its intonation, broadly in line with Hunyadi's (2002) views on the relationship between prosody and semantics; see Mycock (2010a).

${ }^{10}$ McDaniel (1989) calls these "true wh-phrases".

${ }^{11}$ The native speakers that I consulted for this study indicated one exception to this generalization: when the question phrases bear the grammatical functions direct object and indirect object, they strongly preferred one to appear in sentence-initial position while the other occupied sentence-final position. For example:

(i) Koga je Roman hvalil KOMU?

'Who did Roman praise to who?'

Given the restricted nature of this question phrase distribution, such questions are excluded from the following discussion.

${ }^{12}$ Note that the complementizer $d a$ 'that' is also a clitic (Toporišič 1984). 
${ }^{13}$ Golden (1996) claims otherwise, however the native speakers I consulted were in accord with Marušič (2008): they too found multiple fronting of question phrases from one finite clause to a higher one unacceptable.

${ }^{14}$ Ljubljana sits on the border between two distinct Slovenian dialect types, one tonemic and one non-tonemic (Greenberg 2003: 236). There are contradictory reports in the literature regarding whether or not the dialect of Slovenian spoken in Ljubljana is tonemic (e.g. Gvozdanović 1999: 848; Šuštaršič \& Tivadar 2005; Marušič \& Žaucer 2006; Woznicki 2006; Jurgec 2007). This paper is concerned with intonation at the sentence level. The issue of whether Standard Slovenian is tonemic or not is set aside. 15 This may be why Šuštaršič (2005) claims that the remainder of the utterance following a clause-initial question word is 'unstressed'. This claim requires further experimental investigation. See also footnote 7 for a related point on the Hungarian data.

${ }^{16}$ The overall falling pattern does not mean that variations in pitch do not occur after the initial $\mathrm{H}$ pitch accent. Notice the difference between the second and third words in (34), (35), and (36).

Author's address: Faculty of Linguistics, Philology and Phonetics,

University of Oxford,

Somerville College,

Woodstock Road, Oxford OX2 6HD, United Kingdom

louise.mycock@ling-phil.ox.ac.uk 